\title{
北海道と埼玉県の採卵鶏農場の衛生対策の実践と 関連する社会学的因子
}

\author{
伊藤弘貴 $\cdot$ 中原裕貴 ·渡部卓人 $\cdot$ 蒔田浩平* \\ 酪農学園大学獣医学群獣医疫学ユニット
}

\begin{abstract}
【目 的】
農場経営者の衛生意識は, 農場防疫レベルの高さに関与 すると考えられる。

本研究では, 2004 年に農林水産省が施行した飼養衛生 管理基準項目の遵守割合を用い, 採卵鶏農場における衛生 対策の実践と関連する社会学的因子を明らかにすることを 目的とした。
\end{abstract}

\section{【材料および方法】}

個人属性, 農場形態, 知識, 態度, 飼養衛生管理基準項 目の遵守に関する質問票を作成し，2014 年 5 月に北海道 の養鶏農家 60 名及び埼玉県の養鵎農家 98 名を対象として 郵送法で質問票調查を行った。

単変量解析では, 飼養衛生管理基準の遵守割合と二項, カウント, スコア変数を含む各質問項目との関係性につい て, 帰無モデルとの比較には分散分析を用いながら, 一般 化線形モデル準二項䛊差により解析を実施した。なお統計 解析には統計ソフト R を使用した。さらに, 多変数解析 では, 単変量解析において $\mathrm{p}$ 值が 0.2 以下であった因子を 説明変数, 各農場における飼養衛生管理基準の遵守割合を 目的変数として一般化線形モデル準二項誤差を用いて最適 化を行った。北海道についてはサンプル数が少なかったた め, 多变数解析は実施しなかった。

\section{【結果と考察】}

回収率は北海道で $33.3 \% （ 20 / 60 ）$, 埼玉県で $40.8 \% （ 40 /$
98）であった。平均遵守割合は北海道 (64.8\%) と埼玉県 (65.2\%) との間で有意に異ならなかった $(\mathrm{p}=0.81)$ 。

北海道に抢ける単変量解析の結果より, 遵守割合の高さ と関連する因子は, ウインドウレス形式での飼育 $(\mathrm{p}=$ $0.03)$, 農業従事者数が多いこと $(\mathrm{p}=0.04)$, 過去 10 年以 内の疾病発生種類が多いこと $(\mathrm{p}=0.04)$, 家畜伝染病予防 法の内容の把握 $(\mathrm{p}<0.01)$, 家畜伝染病予防法の改正によ

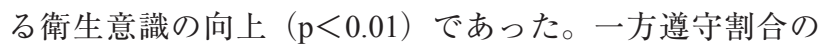
低さと関連する因子は, 農業協同組合 (JA) を衛生知識 の入手先としていた $(\mathrm{p}=0.01)$ ことであった。

埼玉県においては, 遵守割合の高さと関連する因子は, 長い労働時間 $(\mathrm{p}<0.01)$, 農場経営における関連団体数が 多いこと $(\mathrm{p}<0.01)$, 自農場の衛生対策に対する満足度が 高いこと（p=0.01）であった。また遵守割合の低さと関 連する因子は, 家族経営 $(p=0.02)$, 民間会社を衛生知識 の入手先としていること $(\mathrm{p}<0.01)$ であった。

結果から, 良好な防疫対策を実施している養䳕農場の特 徵として, 商業化が進んでおり, 衛生意識の高い農場経営 者集団を含む信頼性のある情報源から積極的に情報を入手 していること, 過去に複数の疾病発生を経験していること が挙げられた。一方で, 小規模で, 農場衛生が専門業務で ない組織から衛生知識を入手している農場で遵守割合が低 かった。以上から，小規模採卵鶏農場に扔ける衛生情報の 支援と, 少ない労働力で実施可能な防疫技術の提供により 採卵鶏農場全体の防疫レベルのさらなる向上が達成出来る と考えられた。

連絡先 : 䓓田浩平*

酪農学園大学獣医学群獣医疫学ユニット

厂069-8501 北海道江別市文京台緑町 582 番地

Tel \& Fax : 011-388-4761

E-mail : kmakita@rakuno.ac.jp 


\title{
Sociological Factors Associated with Practice of Hygiene Management in Layer Farms in Hokkaido and Saitama Prefectures in Japan
}

\author{
Hirotaka ITO, Yuki NAKAHARA, Takuto WATANABE and Kohei MAKITA \\ Veterinary Epidemiology Unit, Rakuno Gakuen University, Japan
}

\begin{abstract}
【Objectives】
Hygiene awareness of farmers is assumed to be associated with bio-security level in their farms.

The purposes of this study were to reveal the sociological factors associated with the practice of hygiene management in layer farms, using the proportion of items complied among the Standard of Rearing Hygiene Management (SRHM), which took effect in 2004 by Ministry of Agriculture, Forestry and Fisheries.

\section{【Materials and Methods】}

A questionnaire regarding personal attributes, farm type, knowledge, attitude, and compliance with SRHM was designed, and distributed to 60 and 98 farmers in Hokkaido and Saitama Prefecture, respectively in May 2014 as a postal survey.

In the univariate analysis, the relationship between the proportion of compliance with SRHM and each item asked, including binary, count, and scored responses was analyzed using Generalized Linear Models (GLMs) with quasi-binomial errors comparing the null model using Analyses of Variance (ANOVAs) in statistical software R. In the multivariable analysis, model simplification was performed using GLMs with quasi-binomial errors, choosing the proportion of compliance as response variable and the factors with $\mathrm{p}$ value less than 0.2 in univariate analysis as explanatory variables. Multivariable analysis was not performed for Hokkaido farms, as the number of responses was small.
\end{abstract}

\section{【Results and Discussion】}

The response rates were 33.3\% (20/60) and 40.8\% (40/98) in Hokkaido and Saitama, respectively. The mean proportions of compliance with SRHM were not significantly different between Hokkaido $(64.8 \%)$ and Saitama $(65.2 \%, p=0.81)$.

In the univariate analysis in Hokkaido, the factors associated with high proportion of compliance were windowless type $(\mathrm{p}=$ $0.03)$, larger number of employee $(p=0.04)$, larger diversity of infectious diseases occurred in the last decade $(p=0.04)$, knowing the contents of Act on Domestic Animal Infectious Diseases Control $(\mathrm{p}<0.01)$, and improvement of hygiene awareness by the renewal of the Act. The factor associated with low proportion of compliance was obtaining information on hygiene from Japan Agricultural Cooperatives (JA) $(\mathrm{p}=0.01)$.

In Saitama, the factors associated with high proportion of compliance were longer working time $(\mathrm{p}<0.01)$, larger number of organizations to work with $(\mathrm{p}<0.01)$, and being satisfied with own hygiene practice $(\mathrm{p}=0.01)$. In contrast, the factors associated with low proportion of compliance were working in a family-owned farm $(\mathrm{p}=0.02)$ and obtaining information of hygiene from private companies $(\mathrm{p}<0.01)$.

These results suggested that farms with better bio-security practice were characterized by commercialized farms actively collecting hygiene information through reliable source including highly motivated farmers' group, and experience of disease occurrences, while farms with weaker bio-security were by smaller scale and collecting hygiene information from organizations not specialized on animal hygiene.

Further improvement of bio-security level among layer farms may be achieved by supporting smallholder farms on sound acquisition of hygiene information and providing low labor hygiene management techniques. 


\title{
北海道と埼玉県の酪農場の衛生対策の 実践と関連する社会学的因子
}

\author{
中原裕貴 ·渡部卓人・浅倉真吾・蒔田浩平* \\ 酪農学園大学獣医学群獣医疫学ユニット
}

\begin{abstract}
【目 的】
農場経営者の衛生意識は, 農場防疫レベルの高さに関与 すると考えられる。

本研究では, 2004 年に農林水産省が施行した飼養衛生 管理基準項目の遵守割合を用い, 酪農場における衛生対策 の実践と関連する社会学的因子を明らかにすることを目的 とした。
\end{abstract}

\section{【材料および方法】}

個人属性, 農場形態, 知識, 態度, 飼養衛生管理基準項 目の遵守に関する質問票を作成し， 2013 年 12 月に北海道 の酪農家 290 名及び埼玉県の酪農家 308 名を対象として郵 送法で質問票調査を行った。

単変量解析では, 飼養衛生管理基準の遵守割合と二項 · カウント・スコア変数の各質問項目との関倸性について, 帰無モデルとの比較には分散分析を用いながら一般化線形 モデル準二項誤差にて解析を実施した。統計解析には統計 ソフト R を使用した。さらに, 多変数解析では, 単変量 解析に扔いて $\mathrm{p}$ 值が 0.2 以下であった因子を説明変数, 各 農場における飼養衛生管理基準の遵守割合を目的変数とし て一般化線形モデル準二項誤差を用いて最適化を行った。
連絡先: 蒔田浩平*

酪農学園大学獣医学群獣医疫学ユニット

T069-8501 北海道江別市文京台緑町 582 番地

Tel \& Fax : 011-388-4761

E-mail : kmakita@rakuno.ac.jp

\section{【結果と考察】}

回収率はそれぞれ北海道で 29.7\%（86/290), 埼玉県で 44.2\% (136/308) であった。平均遵守割合は北海道 (61.5\%) と埼玉県 $(56.0 \%)$ との間で有意に異ならなかった $(\mathrm{p}=$ 0.08)。

北海道において遵守割合の高さに関連する因子は，農場 経営における関係団体数が多いこと $(\mathrm{p}=0.01)$, 農場内衛 生対策を仕事の中で優先していること $(\mathrm{p}=0.03)$, 飼養衛 生管理基準の改正後他農場とのコミュニケーション頻度が 減少したこと $(p=0.02)$ であった。埼玉県において遵守割 合の高さに関連する因子は, 農場経営における関係団体数 が多いこと $(\mathrm{p}<0.01)$, 農業従事者数が多いこと $(\mathrm{p}=0.04)$, 労働時間が長いこと $(p=0.02)$, 繁殖成績を仕事の中で優 先していること $(\mathrm{p}=0.05)$, 過去 10 年以内の伝染性疾病発 生種類数が多いこと $(\mathrm{p}=0.02)$ であった。

両地域における結果から, 多くの組織と繋がりを持つ大 規模農場に代表されるような高能力酪農場は飼養衛生管理 基準の遵守に対して意欲的だった。埼玉県で見られた遵守 割合と繁殖成績の優先との関倸性については, 今後さらに 解析が必要である。コミュニケーション頻度の減少と伝染 病発生の経験に見られたように, 伝染性疾病に対する警戒 心の高さが高い遵守率と関係していると思われる。特に小 規模農場を対象としたコミュニケーション方法の改善によ り, 衛生意識が向上され，それにより農場防疫が改善され ると考えられる。 


\title{
Sociological Factors Associated with Practice of Hygiene Management in Dairy Farms in Hokkaido and Saitama Prefectures in Japan
}

\author{
Yuki NAKAHARA, Takuto WATANABE, Shingo ASAKURA and Kohei MAKITA \\ Veterinary Epidemiology Unit, Rakuno Gakuen University, Japan
}

\section{【Objective】}

Hygiene awareness of farmers is assumed to be associated with bio-security level in their farms.

The objectives of this study were to reveal the sociological factors associated with the practice of hygiene management, using the proportion of items complied among the list of the Standard of Rearing Hygiene Management (SRHM), which took effect in 2004.

\section{[Material and Methods】}

A questionnaire regarding personal attributes, farm type, knowledge, attitude, and compliance with SRHM was designed, and distributed to 290 and 308 dairy farmers in Hokkaido and Saitama Prefectures, respectively, in December 2013 as a postal survey.

In the univariate analysis, the relationship between the proportion of compliance and each item in the questionnaire was analyzed using Generalized Linear Models (GLMs) with quasi-binomial errors, comparing with null model using Analysis of Variance (ANOVA) in statistical software, R. In the multivariable analysis, model simplification was performed using GLM with quasibinomial errors, choosing the proportion of compliance as the response variable and factors with p value less than 0.2 in the univariate analyses as explanatory variables.

\section{【Result and Discussion】}

The response rates were 29.7\% (86/290) and 44.2\% (136/308) in Hokkaido and Saitama, respectively. There was no significant difference in the proportion of compliance between Hokkaido (61.5\%) and Saitama $(56.0 \%, \mathrm{p}=0.08)$.

In Hokkaido, the factors associated with high proportion of compliance were larger number of organizations to work with ( $\mathrm{p}=$ $0.01)$, prioritizing hygiene management among farming activities $(p=0.03)$, and the decreased frequency of communication with other farmers after SRHM was revised $(\mathrm{p}=0.02)$. In Saitama, the factors associated with high compliance were larger number of organizations to work with $(\mathrm{p}<0.01)$, larger number of employee $(\mathrm{p}=0.04)$, longer working time $(\mathrm{p}=0.02)$, prioritizing reproduction performance among farming activities $(\mathrm{p}=0.05)$, and larger diversity of infectious diseases occurred in the last decade $(\mathrm{p}=0.02)$.

From the results in two areas, dairy farms with higher capacity, such as large scale farms with connections with many organizations, had high attitude towards compliance with SRHM. Additional analysis would be needed for the association with compliance and prioritizing reproduction performance in Saitama. Vigilance against infectious diseases, seen from the association with decreased frequency of communication and disease experiences, seemed to be associated with high compliance. Improvement in communication with farmers, especially smallholders, may increase hygiene awareness, which would improve farm bio-security. 


\title{
北海道のめん羊農場における衛生対策の実践と関連する社会学的因子
}

\author{
田村祐斗・中原裕貴 ·渡部卓人 ・蒔田浩平 ${ }^{*}$ \\ 酪農学園大学獣医学群獣医疫学ユニット
}

\begin{abstract}
【目 的】
農場経営者の衛生意識は, 農場防疫レベルの高さに関与 すると考えられる。

本研究では 2004 年に農林水産省が施行した飼養衛生管 理基準に定められている項目の遵守割合を用い，めん羊農 場に扔ける衛生対策の実践と関連する社会学的因子との関 係を明らかにすることを目的とした。
\end{abstract}

\section{【材料および方法】}

質問票は, 個人属性, 農場形態, 農場衛生に対する知識 や態度, 飼養衛生管理基準の遵守について作成した。2014 年 4 月に質問票を送付し, 北海道のめん羊農家 67 名を対 象として郵送法で調查を行った。

単変量解析では, 各農場における飼養衛生管理基準の遵 守割合と, 二項, カウント, スコア変数を含む質問票の各 質問項目との関連について, 帰無モデルとの比較には分散 分析を用いながら，一般化線形モデル準二項誤差により解 析した。統計解析には統計ソフト R 使用した。多変数
解析では, 単変量解析において $p$ 值が 0.2 以下であった因 子を説明変数, 各農場における飼養衛生管理基準の遵守割 合を目的変数として一般化線形モデル準二項誤差を用いて 最適化を行った。

\section{【結果と考察】}

回収率は 49.3\%（33/67）であった。また平均遵守割合 は $66.1 \%$ であった。遵守割合の高さと関連する因子は 3 つであった：(1) 自農場の衛生対策への満足 $(\mathrm{p}=0.02)$, (2) 短い就農年数 $(\mathrm{p}=0.02),(3)$ 家畜伝染病予防法改正後の 農場訪問者の衛生意識に対する危機感の増加 $(\mathrm{p}=0.02)$ 。 一方で遵守割合の低さと関連する因子は, 衛生知識の他農 家からの入手（ $\mathrm{p}=0.04 ）$ であった。

特に就農年数が短い, 衛生意識が高いめん羊農家では上 手く防疫が実践出来ており, その結果満足感が得られてい ると考えられた。衛生知識は衛生意識を変化させることが 考えられることから, 衛生情報の提供方法の改善によりめ 几羊農場防疫のさらなる強化を達成することが出来ると考 えられた。
連絡先: 蒔田浩平*

酪農学園大学獣医学群獣医疫学ユニット

T069-8501 北海道江別市文京台緑町 582 番地

Tel \& Fax : 011-388-4761

E-mail : kmakita@rakuno.ac.jp 


\title{
Sociological Factors Associated with Practice of Hygiene Management in Sheep Farms in Hokkaido Prefecture in Japan
}

\author{
Yuto TAMURA, Yuki NAKAHARA, Takuto WATANABE and Kohei MAKITA \\ Veterinary Epidemiology Unit, Department of Veterinary medicine, Rakuno Gakuen University \\ 【Objective】
}

Hygiene awareness is assumed to be associated with bio-security level in their farms. The purposes of this study were to reveal the sociological factors associated with the practice of hygiene management in sheep farms using the proportion of items complied among the list in the Standard of Rearing Hygiene Management (SRHM), which took effect in 2004 by Ministry of Agriculture, Forestry and Fisheries.

\section{【Materials and Methods】}

A questionnaire regarding personal attributes, characteristics of a farm, knowledge and attitude on farm hygiene, and compliance with SRHM was designed, and distributed to 67 sheep farmers as a postal survey in April 2014.

In the univariate analysis, the relationship between the proportion of compliance with SRHM and each item asked, including binary, count, and scored responses, was analyzed using Generalized Linear Models (GLMs) with quasi-binomial errors, comparing the null model using Analysis of Variance (ANOVA) in statistical software R. In the multivariable analysis, model simplification was performed using GLM with quasi-binomial errors, choosing the proportion of compliance as response variable and the factors with $p$ value less than 0.2 in univariate analysis as explanatory variables.

\section{【Results and Discussion】}

The response rate was $49.3 \%$ (33/67). The mean proportion of compliance was $66.1 \%$.Three factors were associated with high proportion of compliance : (1) being satisfied with own hygiene practice $(p=0.02),(2)$ shorter experience of farming $(p=0.02)$, (3) increased vigilance on hygiene against farm visitors after the revision of Act on Domestic Animal Infectious Diseases Control $(p=$ 0.02). There were also a factor associated with low proportion of compliance - obtaining knowledge about hygiene from other sheep farmers $(\mathrm{p}=0.04)$.

Vigilant sheep farmers with high hygiene awareness, especially recently started ones, performed better bio-security practice, which gave satisfaction to them. Hygiene knowledge may change hygiene awareness, and thus improvement in provision of hygiene information may strengthen bio-security in sheep farms further. 


\title{
東南アジアおよび沖縄県におけるヤモリ由来 Salmonella Weltevreden の分子遺伝子型別
}

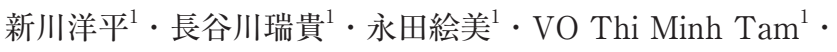 \\ NGUYEN Khanh Thuan ${ }^{1} \cdot$ LY Thi Lien Khai ${ }^{2}$ 谷口隆秀 ${ }^{1}$ 林谷秀樹 ${ }^{1 *}$ \\ ${ }^{1}$ 東京農工大学 $\cdot{ }^{2}$ Can Tho 大学
}

\section{【目 的】}

東南アジア地域では, 感染患者から Salmonella Weltevreden が最も高率に分離されることが報告されており, 重要な血 清型となっている。また, 日本に扔いても, 沖縄県ではよ くみられる血清型の一つである。これらの地域では野生ヤ モリがS.Weltevreden のレゼルボアとなっている可能性が 指摘されており, ヤモリから分離された菌株の遺伝的関連 性を調べることは重要である。本研究では, ヤモリ由来扔 よびヒトの胃腸炎患者由来の S.WeltevredenにPFGEを応 用し, 遺伝的関連性を評価した。あわせて, 分子疫学的型 別法の一つである Multiple-locus variable-number tandem repeat analysis（MLVA）法をS.Weltevreden に応用し, 本血 清型を型別するのに有効となるプライマーセットを検証し た。

\section{【材料および方法】}

ベトナム・メコンデルタ 1市 2 省 (Can Tho 市, Ca Mau 省抢よび Kien Giang 省）由来 25 株, ベトナム・フエ由来 19 株, カンボジア・シエムリアップ由来 16 株, タイ由来 株 16 株, 沖縄県由来 2 株のヤモリ由来株計 78 株と, ベト ナム・メコンデルタ（Can Tho 市）で分離されたヒトの胃 腸炎患者由来株 3 株を加えた計 81 株の S.Weltevreden につ いて，パルスフィールドゲル電気泳動（PFGE）法を用い て分子遺伝子型別を行い, 得られたパターンから系統図を 作製した。また, シーケンス解析による分子遺伝子型別法
の一つである MLVA 法も合わせて実施した。

\section{【結果と考察】}

1. 供試したS.Weltevreden 81 株は, PFGE 法により 22 のパターンに型別された。これらの菌株のうち, 複数の地 域から同一の PFGE パターンが得られたものは 2 パターン のみであった。また, 系統戝解析から, それぞれの地域か ら得られた菌の大部分は同じクラスターに分類されること が分かった。これらのことから, 調查した東南アジアにお いては, 古くから多様な遺伝子タイプの S.Weltevreden が 分布しており，やがてそれぞれの地域に生息するヤモリと ともに分化していったものと考えられる。また, 胃腸炎患 者由来 3 株のうち 2 株と同じ PFGE パターンがヤモリ由来 株に扔いても観察されたことから, 東南アジアではヤモリ がS.Weltevredenのヒトへの感染源として重要な役割を果 たしている可能性が示された。

2. PFGEで異なる22のPFGEパターンを示したS. Weltevreden 29 株は, MLVAによって14 タイプに型別され た。このことから, 今回実施した MLVA の菌株型別能は, PFGE よりも低いことが明らかとなった。しかし, 今回 PCR の標的とした 4 領域中 2 領域のみが多型性をもつ領 域であったため, 多型性が高い領域を検索し，それに対す るプライマーを作成し MLVAを行うことができれば, PFGE と同等のまたはそれ以上の菌株型別能力を発揮する 可能性も考えられる。
連絡先 : 林谷秀樹*

東京農工大学大学院農学研究院

干183-8509 東京都府中市幸町 3-5-8

Tel \& Fax : 042-367-85775

E-mail : eisei@cc.tuat.ac.jp 


\title{
Molecular Epidemiological Analysis of Salmonella Weltevreden Originated from Wild Gecko in Southeast Asia Countries and Okinawa Prefecture
}

\author{
Yohei SHINKAWA ${ }^{1}$, Mizuki HASEGAWA ${ }^{1}$, Emi NAGATA ${ }^{1}$, VO Thi Minh Tam ${ }^{1}$, NGUYEN Khanh Thuan ${ }^{1}$, \\ LY Thi Lien Khai ${ }^{2}$, Takahide TANIGUCHI ${ }^{1}$ and Hideki HAYASHIDANI ${ }^{1}$ \\ ${ }^{1}$ Tokyo University of Agriculture \\ ${ }^{2}$ Can ThoUniversity
}

Salmonella Weltevreden are frequently isolated from human patients not only in Southeast Asian countries but also Okinawa prefecture. Wild gecko seems to be an important reservoir of this serovar in those regions. In this study, pulsed-field gel electrophoresis (PFGE) analysis and multiple-locus variable-number tandem repeat analysis (MLVA) among $S$. Weltevreden isolates originated from wild gecko and human patients was done to know genetic relationship among them.

Total of 81 S.weltevreden isolates including 78 from wild gecko (44 Vietnam, 16 Cambodia, 16 Thailand and 2 Okinawa prefecture) and 3 from human patients in Vietnam were analyzed by PFGE and MLVA.

1. Twenty-two PFGE patterns were obtained from $81 \mathrm{~S}$. Weltevreden isolates originated wild gecko. PFGE pattern of $S$.Weltevreden isolates obtained from the same region were categorized into the same cluster. These results indicate that several genetic type of $S$.Weltevreden had been prevalent in wild gecko in Southeast Asia region for a long time. After that, this serovar seemed to be diversified by each region.

2. Twewnty-nine $S$.Weltevreden isolates showing 22 PFGE patterns were typed into 14 MLVA pattern. These results indicate that discriminate power of MLVA in this study is lower than PFGE. Further research should be done to find suitable primer for MLVA. 


\title{
西日本における重症熱性血小板減少症候群（SFTS）の 猟犬を用いた血清学的調査
}

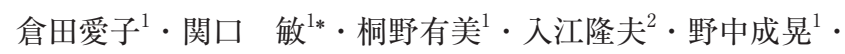 \\ 堀井洋一郎 ${ }^{1} \cdot$ 下島昌幸 ${ }^{3} \cdot$ 黑田嘉紀 $^{4} \cdot$ 乗峰潤三 $^{1}$ \\ ${ }^{1}$ 宮崎大学農学部 $\cdot{ }^{2}$ 北海道立衛生研究所 ${ }^{3}$ 国立感染症研究所 $\cdot{ }^{4}$ 宮崎大学医学部
}

\section{【目 的】}

重症熱性血小板減少症候群 (SFTS : severe fever with thrombocytopenia syndrome) は, 2013 年 1 月に初めて日本 での症例が確認され, 以来西日本を中心に多数の人及び動 物に㧍ける感染が報告されている人獣共通感染症である。 本症は Bunyaviridae 科の Phlebovirus 属に属するウイルス がマダニを媒介して人や動物に感染することによって起こ る。野生動物の保存血清を用いた血清学的調查から, 本ウ イルスは 2013 年以前から日本に存在していたことが明ら かとなっている。しかしながら, 日本国内の地域レベルに おけるウイルスの分布は明らかになっていない。本ウイル スはマダニ間，マダニ-動物間で循環し生存しているため, ウイルスの浸潤状況を把握するためには, マダニおよび動 物に扔ける調査が必要である。特に野生動物における調査 が重要であるが, 血清の確保が容易ではない。そこで我々 は野生動物が多く生息する地域で活動する猟犬に着目し, 過去に収集された宮崎県を中心とする西日本地区の猟大の 血清を用いて, SFTS ウイルス（SFTSV）に対する抗体の 有無を検查した。

\section{【材料および方法】}

2002 年から 2011 年にかけて採取した西日本地区の猟犬 血清 371 検体の血清中の抗 SFTS 抗体について, SFTSV-
感染 Huh7 細胞を抗原とする ELISA 法により検査した。

\section{【結果と考察】}

西日本全体では 371 頭中 91 頭 $(24.5 \%)$, 宮崎県では 234 頭中 89 頭（38.0\%）がSFTSVに対して陽性を示した。 陽性検体は西日本のあらゆる地域において散在性に存在し ていた。また 2003 年に採血した血清からも抗体が検出さ れたことから, ヒトの初発感染の報告より 10 年以上前に 既に宮崎県ではSFTS ウイルスが存在していたと考えられ た。SFTS ウイルスの自然界に打ける分布を調査するには, 野生動物の血清学的診断またはマダニからのウイルスゲノ ムの検出が考えられる。西日本では, ほぼ全県, 広範囲で マダニが採取できる。しかし，採取したマダニから SFTS ウイルスが検出されることは極めて稀であるため, マダニ からのウイルスまたはウイルス遺伝子検出による調查は容 易ではない。一方猟犬は, マダニが生息する野山に頻繁に 侵入し，ウイルスを保有するマダニに吸血される機会が多 い。また猟犬からの血清採取は, 野生動物の血清採取に比 べ比較的容易であり,猟を実施した地域を特定できるなど, オーナーを通して有用な情報が取得可能である。今後はこ れらの調査結果と, 本人の同意の下に得られた農業従事者 の血清学的調查の結果を合わせ, SFTSVのヒトへの感染 に関するリスク分析を行う予定である。

\footnotetext{
連絡先 : 関口 敏* 宮崎大学農学部獣医学科 産業動物伝染病防疫学研究室 干 889-2192 宮崎市学園木花台西 1-1 Tel \& Fax : 0985-58-7676 E-mail : sekiguchi@cc.miyazaki-u.ac.jp
} 


\title{
Serological Survey of the Severe Fever with Thrombocytopenia Syndrome Virus (SFTSV) in Boar-Hunting Dogs in West Japan
}

\author{
Aiko KURATA ${ }^{1}$, Satoshi SEKIGUCHI ${ }^{1}$, Yumi KIRINO ${ }^{1}$, Takao IRIE ${ }^{2}$, Nariaki NONAKA ${ }^{1}$, \\ Yoichiro HORII ${ }^{1}$, Masayuki SHIMOJIMA ${ }^{3}$, Yoshiki KURODA ${ }^{4}$ and Junzo NORIMINE ${ }^{1}$ \\ ${ }^{1}$ Faculty of Agriculture, University of Miyazaki \\ ${ }^{2}$ Hokkaido Institute of Public Health, \\ ${ }^{3}$ National Institute of Infectious Disease \\ ${ }^{4}$ Faculty of Medicine, University of Miyazaki
}

\begin{abstract}
First human case of Severe Fever with Thrombocytopenia Syndrome (SFTS) in Japan was reported in 2013. After then, several human cases have been reported in West Japan. SFTS virus (SFTSV) is believed to be transmitted by ticks because the virus has been detected in Haemaphysalis longicornis ticks and Rhipicephalus microplus tick. From the serosurvey of wild animals, SFTSV is considered to be exist before 2013 in Japan. However, it is not known about the distribution of SFTSV in West Japan. Though the survey of wild animals is important to understand the distribution, it is not easy to collect blood sample from wild animals. In this study, we have focused on boar-hunting dogs for the survey. Boar-hunting dogs enter the mountain and move around in the field when they hunt wild animals. Therefore, to understand the distribution in West Japan, we conducted the serological survey with the sera of boar-hunting dogs in West Japan. We used the ELISA test to detect specific antibody against SFTSV about 371 sera collected from hunting dogs in 18 prefectures during 2002-2011. Positive samples were detected in 91 out of 371 sera (24.5\%) in total, and in 89 out of 234 sera (38.0\%) in Miyazaki prefecture. Positive samples were found in sera collected in 2003, which indicated that SFTSV could exist before 2003. Another way to find the distribution of SFTSV in nature is to detect SFTSV or viral genome from ticks. However, the infected ticks are rarely found in nature. In contrast, the hunting dogs have many opportunities for blood-sucking by ticks in the field. Furthermore, sampling of sera from hunting dogs is easier than wild animals. Then, the serosurvey using hunting-dog sera is useful to understand the distribution of SFTSV infection. To better understand the hazard of the SFTSV, the serological survey with the sera of human and risk analysis will be conducted.
\end{abstract}




\title{
一般演題抄録（6）
}

\section{ベトナム国酪農地帯における乳房炎と繁殖障害の原因の分析}

\author{
小出健太郎 ${ }^{1}$ 村田 $\quad$ 亮 $^{1} \cdot$ AU Xuan Khoa ${ }^{2}$ NGUYEN Khanh Ly ${ }^{2} \cdot$ PHAN Thi Tam ${ }^{2} \cdot$ \\ VU Thi Thu $\mathrm{Tra}^{3} \cdot$ DUONG Van Nhiem ${ }^{3} \cdot$ 耕野拓一 $^{4} \cdot$ 蒔田浩平 ${ }^{1 *}$ \\ ${ }^{1}$ 酪農学園大学・ ${ }^{2}$ National Center of Veterinary Diagnosis · \\ ${ }^{3}$ Vietnam National University of Agriculture ${ }^{4}{ }^{4}$ 帯広畜産大学
}

\begin{abstract}
【目 的】
乳房炎とリピートブリーディングは, 酪農家にとって経 済的に被害の大きい疾病である。本研究では, ベトナムの 酪農地域に打けるそれら疾病の発生状況と, 発生要因の分 析を行った。

\section{【材料および方法】}

対象は乳房炎の臨床症状を呈していない乳牛全頭とし， 1 頭につき 4 分房全てから乳汁を採取し，これを 1 検体と した。合計 162 検体を採取し, それぞれの検体から乳房炎 の原因菌である Coagulase positive Staphylococci，Staphylococcus aureus, Streptococcus agalactiae, Escherichia coli, Klebsiella.sp を対象菌種として細菌学的検查を実施した。 分離された菌に対して 5 種類の薬剂を用いて, デイスク法 による薬剤耐性試験を行った。また質問票で得られた回答 を説明変数, 3 ヶ月以内の乳房炎またはリピートブリー ディングの発生の有無を目的変数として単変量解析ならび に多変量解析を実施することで両疾病の原因を統計学的に 分析した。
\end{abstract}

\section{【結果と考察】}

乳房炎の原因菌は 10.5\%（17/162）の乳汁から検出され

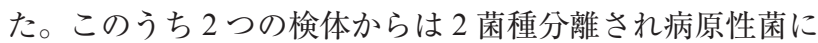
よる混合感染が示唆された。分離された 19 株のうち 94.7\%（18）は伝染性乳房炎の原因菌であった。分離され た全ての伝染性乳房炎原因菌は 1 種類以上の薬剂に対して 耐性を示し，このうち $72.2 \% （ 13 / 18 ）$ は複数の薬剤に耐 性を示した。

多変量解析から潜在性乳房炎のリスク因子は二つ, Van Hoa に農場があること $(\mathrm{OR}=2.9, p=0.02)$ と自家製サイ レージの供給（OR=3.9, $p<0.01 ）$ で，防除因子は濃厚飼 料の供給（ $\mathrm{OR}=0.16, p<0.01 ）$ であった。リピートブリー ディングに関しても濃厚飼料の給与（ $\mathrm{OR}=0.02, p<0.01)$ は防除因子であったが，リスク因子に該当するものはな かった。リピートブリーディングが発生することによって 農家の問題意識は顕著な上昇を示した（Slope of logit $=0.99$, $p<0.01)$ 。

調査地では伝染性乳房炎原因菌が多く，搾乳に打ける衛 生対策が不十分であることが示唆された。多くの菌株が多 郕耐性を示しており，乳房炎の制御に薬剤の不適切な使用 が行われていると考えられる。乳房炎とリピートブリー ディング両疾病のリスク因子と防除因子から乳牛のエネル ギーバランス管理の失宜が推察されたことから，より適切 な飼養管理の指導が両疾病の制御に効果的であると考えら れた。

連絡先 : 蒔田浩平*

酪農学園大学獣医学群獣医疫学ユニット

T069-8501 北海道江別市文京台緑町 582 番地

Tel \& Fax : 011-388-4761

E-mail : kmakita@rakuno.ac.jp 


\title{
Causes of Mastitis and Repeat-breeding of Dairy Herds in a Select Dairy Production Area of Vietnam
}

\author{
Kentaro KOIDE ${ }^{1}$, Ryo MURATA ${ }^{1}$, Xuan Khoa AU², Khanh Ly NGUYEN ${ }^{2}$, Thi Tam PHAN², \\ Thi Thu Tra VU ${ }^{3}$, Van Nhiem DUONG ${ }^{3}$, Hiroichi KONO ${ }^{4}$ and Kohei MAKITA ${ }^{1}$ \\ ${ }^{1}$ Rakuno Gakuen University \\ ${ }^{2}$ National Center of Veterinary Diagnosis \\ ${ }^{3}$ Vietnam National University of Agriculture \\ ${ }^{4}$ Obihiro University of Agriculture and Veterinary Medicine
}

\section{【Objective】}

Mastitis and repeat-breeding cause great economic damages to dairy farms. The objective was to reveal the causes of the aforementioned diseases in a Vietnamese dairy production area.

\section{【Materials and Methods】}

A questionnaire survey and milk sampling were conducted in 97 dairy farms in two communes, Yen Bai and Van Hoa, located in Ba Vi dairy production area of Hanoi District, Vietnam. , A pooled milk sample from all the four teats was collected from milking cows which were not displaying any clinical symptoms of mastitis. In total, 162 milk samples were collected, and bacteriological tests were performed targeted at bacterial species of sub-clinical mastitis : Coagulase-positive Staphylococci, Staphylococcus aureus, Streptococcus agalactiae, Escherichia coli and Klebsiella sp. Disc diffusion antibiotic sensitivity test was performed to examine the drug-resistance against five antibiotics. The questionnaire survey results were analyzed using univariate and multivariable analysis, selecting occurrence of mastitis and repeat-breeding within three months as response variables respectively, to uncover the causes of these problems.

\section{【Result and Discussion】}

The pathogenic bacteria of mastitis were isolated in $10.5 \%(17 / 162)$ of the milk samples. Two different species of pathogenic bacteria were isolated from each of two samples, suggesting infections with multiple pathogens. Out of the 19 isolates, 94.7\% (18) were causal bacteria of contagious mastitis. All the causal bacteria isolates of contagious mastitis were resistant to at least one of the antimicrobials tested, and $72.2 \%(13 / 18)$ to more than two.

Multivariable analysis found two risk factors for subclinical mastitis : farming in Van Hoa $(\mathrm{OR}=2.9, p=0.02)$ and feeding cows home-made silage $(\mathrm{OR}=3.9, p<0.01)$, and a preventive factor : feeding purchased concentrate $(\mathrm{OR}=0.16, p<0.01)$. No risk factor was found for repeat-breading and feeding purchased concentrate to cows $(\mathrm{OR}=0.02, p<0.01)$ was a preventive factor even for this problem. Occurrence of repeat breading significantly raised awareness of the disease (Slope of logit $=0.99, p<0.01$ ).

Contagious mastitis causing bacteria were prevalent and hygiene practice in daily milking may not be adequate. High prevalence of drug-resistance bacteria suggested improper use of antibiotics in mastitis control. Risk and preventive factors for two diseases suggested failure in controlling energy balance of cattle, and that guidance of feed management to farmers seemed to be the effective intervention. 


\title{
鹿児島県・宮崎県における豚流行性下痢（PED）発生拡大の時空間分析
}

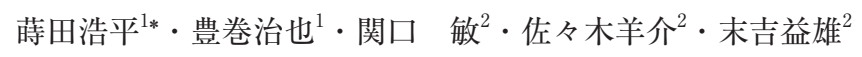 \\ ${ }^{1}$ 酪農学園大学 獣医疫学ユニット \\ 2 宮崎大学 産業動物防疫リサーチセンター
}

\section{【目 的】}

2013 年 10 月に沖縄県で報告された豚流行性下痢 (PED) は全国に感染が拡大し，2015 年 3 月 22 日までに哺乳豚を 中心に 40 万頭以上の豚が死亡している。本研究は, 養豚 場数が多く, 2013 年 12 月から急速な発生拡大が見られた 鹿児島県と宮崎県に扔けるPEDの時間的ならびに空間的 拡大の様式を解析することにより, 農場間伝播の要因を推 察する一助とすることを目的に実施された。

\section{【材料および方法】}

鹿児島・宮崎両県庁の協力の下, 両県内全養豚場（鹿児 島県 709 農場, 宮崎県 506 農場）の所在市町村名, 経営形 態, 飼養頭数抒よび PED 発生の有無と鹿児島県で発生し た 2013 年 12 月 3 日から 2014 年 7 月 24 日までの発生情報 を用いて解析を行った。時間的・空間的クラスターの検出 にはSaTScan（version 9.3.1）を用い, 時間は週単位, 地理 学的単位として市町村を選択し, 発生の有無でのベルヌー イ・モデルによる解析を実施した。

また経営形態, 経営規模, 農場密度について単変量およ び多変数生存分析を実施した。さらに時空間クラスターに おける生存性について分析し, 各県により取られた対策と クラスター内での発生拡大との時間的関連性を検討した。

\section{【結果と考察】}

SaTScan により, 三つの時空間クラスター: 鹿屋, 都城, 宮崎県北クラスターが検出された。鹿屋クラスターは 2013 年 12 月 3 日から翌年 2 月 13 日にかけての流行で,
半径 $16.9 \mathrm{~km}$ のサイズであった。都城クラスターは 1 月 10 日から 30 日にかけての短期間で終息し, 一つの市で発生 したため半径は計算されなかった。宮崎県北クラスターは 3 月 14 日から 4 月 3 日の短期間かつ半径は大きく (32.4 $\mathrm{km})$, 共通感染源感染が示唆された。

生存分析では,一貫経営農場（生存性 7.5）で繁殖（7.8）, 肥育（8.2）よりも有意に生存性が低かった $(p<0.01)$ 。多 変数生存分析では, 全ての経営形態において, 生存性は飼 養頭数が多いほど, また地域の農場密度が高いほど有意に 低かった（肥育: 傾き-0.0002, - 6.3; 一貫 : 傾き -0.0003 , -3.5 ; 繁殖: 傾き $-0.0007,-6.6$; 全てにおいて $\mathrm{p}<0.01)$ 。 農場密度が高い鹿屋クラスターでは繁殖農場で最も大き な割合で発生し $(68.6 \%, 24 / 35)$, 生存性は肥育 $(7.0)$ に 比べて有意に低かった $(5.2,<0.01)$ 。都城クラスターでは 一貫経営農場での発生が最も多く $(39.5 \%, 32 / 81)$, 生存性 は肥育 (8.5) と比較して有意に低かった $(6.6, p<0.01$, 繁 殖は 9.5)。発生はと畜場での消毒徹底開始後迅速に終息し た。宮崎県北でも一貫経営農場で最も多いが 22\%（10/45） での発生に止まり各農場での衛生自己チェック指導後終息 した。宮崎県北クラスター内では経営形態間の生存性に差 は見られなかった。

本研究により, PED 防疫に扔いて, 農場密度が高い地 域での発生初期には特に感受性の高い哺乳豚がいる繁殖農 場と一貫経営農場で素早く拡大しやすいこと, 車両と人の 出入りが多い大型農場で発生しやすいこと, と畜場を介し た共通感染源感染ではと畜場拉よび農場での消毒が有効で あることが示唆された。

連絡先 : 蒔田浩平*

酪農学園大学獣医学群獣医疫学ユニット

T069-8501 北海道江別市文京台緑町 582 番地

Tel \& Fax : 011-388-4761

E-mail : kmakita@rakuno.ac.jp 


\title{
Spatio-temporal Analysis of Spread of Porcine Epidemic Diarrhea (PED) in Kagoshima and Miyazaki Prefecture, Japan
}

\author{
Kohei MAKITA ${ }^{1}$, Haruya TOYOMAKI ${ }^{1}$, Satoshi SEKIGUCHI ${ }^{2}$, Yosuke SASAKI ${ }^{2}$ and Masuo SUEYOSHI ${ }^{2}$ \\ ${ }^{1}$ Veterinary Epidemiology Unit, Rakuno Gakuen University \\ ${ }^{2}$ Center for Animal Disease Control, University of Miyazaki
}

\section{【Purpose】}

Porcine epidemic diarrhea (PED) spread throughout Japan, after the first case in Okinawa in October, 2013 in Okinawa, in Japan, and more than 440,000 pigs, mostly suckling ones, died as of March 22, 2015. This study was conducted to provide information in formulating hypotheses of the factors associated with inter-farm spread, by analyzing spatio-temporal patterns of PED spread in Kagoshima and Miyazaki Prefectures where there were many pig farms and the disease was fast spread since December, 2013.

\section{【Materials and Methods】}

The analyses were conducted using data on administrative units, farm types, number of pigs, and status of infection with PED between December $3^{\text {rd }} 2013$ and July $24^{\text {th }} 2014$, of all the pig farms (709 in Kagoshima and 506 in Miyazaki), with a corporation from both prefectures. SaTScan (version 9.3.1) was used for spatio-temporal disease cluster detection, with week as a unit of time, and township as a unit of geographical area, and in Bernoulli model for the status of infection.

Univariate and multivariable survival analyses were performed for farm type, farm size and farm density. Moreover, survivorship was analyzed for the disease clusters detected, and countermeasures taken by both prefectures were investigated to understand the temporal associations with the disease spread within the clusters.

\section{【Results and Discussion】}

SaTScan found three spatio-temporal clusters : Kanoya, Miyakonojo, and Miyazaki north. Kanoya cluster included the outbreaks between December $3^{\text {rd }} 2013$ and February $13^{\text {th }} 2014$, and the size was $16.9 \mathrm{~km}$ radius. The outbreaks in Miyakonojo cluster stopped in a short time between January $1^{\text {st }}$ and $30^{\text {th }}$, and the radius was not calculated as they were observed in a single city. Miyazaki north cluster also had a short outbreak between March $14^{\text {th }}$ and April $3^{\text {rd }}$, and the radius was quite big (32.4 km), suggesting common source infections.

The survivorship of integrated farms (7.5) was significantly lower than reproduction (7.8) and fattening farms $(8.2, \mathrm{p}<0.01)$. In the multivariable analysis, for all the farm types, survivorship had significant negative relationships with the number of pigs raised and farm density (fattening : slopes $=-0.0002,-6.3$; integrated : $-0.0003,-3.5$; reproduction : $-0.0007,-6.6$; respectively, and $\mathrm{p}<$ 0.01 for all of them).

Reproduction farms had the largest proportion of infection $(68.6 \%, 24 / 35)$ in Kanoya cluster where farm density was high, and the survivorship (5.2) was significantly lower than fattening farms $(7.0,<0.01)$. In Miyakonojo cluster, integrated farms had infection with the largest proportion $(39.5 \%, 32 / 81)$, and the survivorship (6.6) was significantly lower than fattening (8.5) and reproduction farms $(9.5, \mathrm{p}<0.01)$. The outbreaks in the cluster stopped soon after strengthening of disinfection at abattoirs. In Miyazaki north cluster also, integrated farms had largest proportion of infections, but the infection stopped at 22\% (10/45), soon after the introduction of self-hygiene check. There was no significant difference in survivorship among farm types.

This study findings suggested that PED is likely to spread to reproduction and integrated farms where susceptible suckling pigs are raised, especially during the first stage of epidemic in the areas with high farm density, and to large scale farms whose frequencies of vehicle and human entrance are great, and that disinfection at abattoirs and farms would be effective for the common-source infections through abattoirs. 


\title{
豚流行性下痢（PED）の農場内感染モデル
}

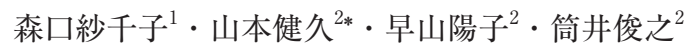 \\ ${ }^{1}$ 新潟大学大学院 自然科学研究科 \\ 2 農研機構 動物衛生研究所 ウイルス・疫学研究領域
}

\section{【目 的】}

豚流行性下痢（PED）は水様性下痢を主な症状とし, 哺 乳豚で高い発症率と死亡率を示す感染症である。日本では 2013 年より発生戸数が急増し, 2014 年 8 月末までに 38 道 県で約 40 万頭が死亡する大規模な流行となった。発生農 場に扔ける感染拡大状況は, 農場の規模や発生後の感染拡 大防止対策などによって異なると考えられる。そこで, PED の有効な感染搪大防止対策を検討するため, PED の 農場内感染を再現する数理モデルを構築し, 飼養規模や衛 生対策の違いが PED の感染拡大に与える影響を検討した。

\section{【材料および方法】}

豚の集団を飼養ステージと感染ステージの違いによって 区分し, それぞれのメ夕個体群の感染動態を再現する数理 モデルを作成した。母豚舎, 分娩舎, 肥育舎の計 3 棟から なる農場を想定し, 飼養ステージは, 母豚舎の母豚, 分娩 舎の母豚と哺乳豚, 肥育舎の肥育豚の 4 つに区分した。豚 舎間の豚の移動として, 母豚は出産時に分娩舎に移動し, 子豚の離乳時に母豚は母豚舎へ, 哺乳豚は肥育舎へそれぞ れ移動し，肥育期を経た肥育豚は出荷されると仮定した。 感染経路として, 環境中のウイルスを介した水平感染と, 感染母豚から生まれた哺乳豚への垂直感染を仮定した。環 境中の PED ウイルスは, 感染豚からの排泄により増加し, 自然減少抒よび清掃・消毒により減少すると仮定するとと もに, 豚舎間の感染豚の移動や作業者等による間接伝播に よって豚舎間を移動すると仮定した。

各豚舎の豚の感染ステージは, 感受性 $(\mathrm{S})$, 潜伏感染 $(\mathrm{E})$, 発症 (I), 不顕性感染（ウイルス排泄あり）(V), 回復 (R),
死亡（D）の6つに区分し，哺乳豚は特に発症・死亡しや すいと仮定した。分婏間隔や発症率などのパラメー夕は, 文献值および専門家の意見を取り入れて決定した。

\section{【結果と考察】}

このモデルを用いて, 母豚 100 頭規模の農場に発症した 母豚 1 頭が導入されてからの感染拡大を 200 日間モニタリ ングした結果, 全ての飼養ステージで発症豚が認められた が, 死亡は哺乳豚だけで認められた。その後 40 日程度で 子豚の死亡が認められなくなり, 母豚舎と分婏舎の感染は 終息したが, 肥育舎では少数の発症豚が継続してみられた。 農場規模を母豚 30 頭規模に減らした場合, 母豚舎以外で は感染が起こらず終息したが，400 頭規模に増やした場合 は 100 頭規模と同様に肥育舎で感染が持続した。

感染拡大防止対策として, ア）豚舎内の消毒の徹底，イ） 豚舎間の機械的なウイルス伝播の防止, ウ）消毒徹底（ア） と伝播防止（イ）の併用，エ）ワクチン接種による哺乳豚 の死亡抑制について, オ）何も対策をしない場合の死亡頭 数及び出荷頭数と比較した。その結果, ワクチン接種を行 なった場合（エ）で哺乳豚の死亡が抑制され, 出荷頭数が 最も多かった。

このように，数理モデルを用いて豚舎内での感染拡大を 再現することにより，PED は大規模な農場で感染が拡大 しやすいことが確認できた。また，消毒を徹底しただけで は感染豚の移動により感染が拡大するため, ワクチン接種 が対策としてょり有効と考えられた。今後は, 実際の感染 農場のデー夕との比較などによりパラメータの信頼性を高 め, より現実的なモデルに改良していく。

\footnotetext{
連絡先 : 山本健久*

国立科学研究法人農業・食品産業技術総合研究機構

動物衛生研究所 ウイルス・疫学研究領域

干 305-0856 茨城県つくば市観音台 3-1-5

Tel \& Fax : 029-838-7769

E-mail : mtbook@affrc.go.jp
} 


\title{
Within-farm Transmission Model of Porcine Endemic Diarrhea (PED)
}

\author{
Sachiko MORIGUCHI ${ }^{1}$, Takehisa YAMAMOTO ${ }^{2}$, Yoko HAYAMA ${ }^{2}$ and Toshiyuki TSUTSUI ${ }^{2}$ \\ ${ }^{1}$ Department of Environmental Science, Graduate School of Science and Technology, Niigata University \\ ${ }^{2}$ Viral Disease and Epidemiology Research Division, National Institute of Animal Health
}

\section{【Objective】}

Porcine endemic diarrhea (PED) is a viral infectious disease causing watery diarrhea, and it affects most severely neonatal piglets with high morbidity and mortality. In Japan, a large scale epidemic occurred in 2013, and about 400,000 pigs died in 38 prefectures by the end of August 2014. The manner of PED transmission is considered to differ depending on farm size and/or control measures taken after the initial detection of the disease. To consider effective control measures for PED transmission, we aimed to develop a mathematical model that simulates within-farm transmission of PED, and discussed the impacts of different farm sizes and control measures on the disease transmission.

\section{[Materials \& Methods】}

A mathematical model was built to simulate the transmission dynamics in a fallow-to-finish pig farm. A pig population in the farm was divided into several compartments by both production stages and infection stages. Three pig houses (breeding house, farrowing house and fattening house) was assumed, and production was classified into four stages, namely, breeding sows in breeding house, breeding sows in farrowing house, neonatal piglets in farrowing house and fattening pigs in fattening house. Breeding sows kept in breeding house were moved to farrowing house before giving birth to their piglets. After weaning, sows were returned to breeding house and piglets were moved to fattening house. Subsequent to the fattening period, fattening pigs were removed from the farm for slaughter. For the infection route, horizontal transmission via contaminated environment and vertical transmission from infected sows to their offspring were assumed. It was also assumed that excretion of virus occurred from clinical and subclinical pigs to the surrounding environment, while the virus load was reduced by natural decay or disinfection of the environment. Disease transmission between pig houses was assumed to be caused by movement of infected pigs and other mechanical transmission such as movements of farm employees between houses.

Infection stages were defined as susceptible (S), latent (E), subclinically infectious (V), clinically affected (I), recovered (R) and death (D). Pre-weaning piglets were assumed to be easily affected and show higher mortality. Parameter values such as farrowing interval and infection rate were determined based on previously published papers and expert opinions.

\section{【Results \& Discussion】}

Using this model, the disease transmission after introduction of one infected sow into a farm with 100 breeding sows was monitored for 200 days. Infections were occurred in every production stage, but death was confirmed only in neonatal piglets. About 40 days after the disease introduction, the death of piglets stopped and infection among pigs in breeding house and farrowing house ended, but a small number of infected pigs were still observed in fattening house. In case of small farm with 30 breeding sows, infection was limited to breeding house. In large (400 sows) sized farm, subclinical infection persisted in fattening pigs throughout the study period.

With respect to control measures, 1) complete disinfection of pig houses, 2) prevention of viral transmission between pig houses, 3) combination of 1) and 2), 4) vaccination to reduce mortality in neonatal piglets, 5) no measures, were compared in terms of the number of deaths and pigs shipped for slaughter. The simulation results showed that vaccination induced the lowest mortality in neonatal piglets and the largest number of pigs for slaughter.

The spread of PED infection within farm was simulated with a mathematical model. It was confirmed that PED was more likely to spread at a larger sized farm. In this simulation study, infection spread by movement of pigs, therefore vaccination was deemed as the most effective control measure. In the future study, the reliability of the parameters should be improved by taking into account the empirical data from the outbreak. 


\title{
感染症モデリングを用いた 我が国に狂犬病侵入した場合の流行拡大の解析
}

\author{
${\text { 門脇 } \quad \text { 弾 }^{1} \cdot \text { Katie HAMPSON }{ }^{2} \cdot \text { 蒔田浩平 }^{1 *} \cdot \text { 山田章雄 }}^{3}$ \\ ${ }^{1}$ 酪農学園大学 獣医疫学ユニット・ ${ }^{2}$ Glasgow University $\cdot{ }^{3}$ 東京大学大学院
}

\begin{abstract}
【目 的】
我が国は 1957 年の発生を最後にその後の輸入症例を除 いて狂犬病発生のない清浄国である。しかしながら，我が 国を取り巻く社会情勢は狂犬病が流行していた当時と比べ 大きく変化し, 狂犬病拡大のリスクが以前とは異なる可能 性が考えられる。この状況を踏まえ, 狂犬病予防法の改正 が議論されている。そこで本研究では, 我が国に狂犬病が 侵入した場合の発生と拡大の過程をシミュレーションする ことで, 狂犬病拡散のリスクを定量化することを目的とし た。
\end{abstract}

\section{【材料および方法】}

本研究では, 狂犬病の拡大が各個体と飼主の行動が関連 していると考えられるため, 各個体の動きを描写する個人 ベースド・モデルを用いた。パラメータには，人口密度， ワクチン接種率, 基本再生産数, 狂犬による咬傷で新規狂 犬が発生する確率および世代間隔を用いた。新規狂犬が発 生する確率は, 移動カーネルと人口密度によって表される と仮定し, 距離カーネルに関してはタンザニアの事例から 推定された距離カーネルを調節した。基本再生産数及び新 規狂犬が発生する確率は大阪府に抢ける大正 3 年から昭和 8 年までの狂犬病発生のデー夕を用いて推定した。

また, 現在の我が国に扔ける狂犬病拡散のモデルを構築 するにあたり，日本全土をモデル化し，解析を行うことは 不可能なため, 狂犬病拡散のリスクが高いと考えられた北 海道と茨城県を選択した。地理データには両道県の行政区 域デー夕を用いた。人口密度, 飼育頭数, 放浪犬の数㧍よ
びワクチン接種率は市町村毎のデー夕を用い, 不均一性を 表現した。シミュレーションは 500 回行い, 第 1 症例の発 生場所はそれぞれのシミュレーション毎にランダムに選択 した。また，ワクチン接種の効果を検討するため，市町村 毎のワクチン接種率の違いを保ったままワクチン接種率を $10 \%$ と $20 \%$ 低くして同様に 500 回のシミュレーションを 行った。なお, 狂犬病発生時に行われる発生時措置は行わ れないものとした。

\section{【結果と考察】}

パラメー夕推定に関して, 基本再生産数は 2.8 , 移動カー ネルと人口密度を調節するパラメー夕は, それぞれ 2.28 および 2.24 であった。

狂犬病拡散シミュレーション結果に関して, 札幌市周辺 ではワクチン接種率が $55 \%, 45 \%$ 及び $35 \%$ のとき，狂犬 病発生数の中央值はそれぞれ 2 頭, 4 頭, 354 頭であった。 また，発生から終息までの期間については，それぞれ 53.5 日，92.5 日及び 339.5 日であった。水戸市周辺でのシミュ レーション結果に関して, ワクチン接種率が $55.6 \%$, $45.6 \%$ 及び $35.6 \%$ のとき, 狂犬病発生数の中央值はそれぞ れ 2 頭, 3 頭, 389 頭であった。また, 発生から終息まで の期間については，それぞれ 35 日，89.5 日及び 397.5 日 であった。

本研究により, 地域全体のワクチン接種率が低下すると, 狂犬病発生数が多くなり, 終息までの期間が延長されるこ とが明らかになった。今後, 飼育形態や狂犬病予防対策を 反映したモデルを構築し, 現行の予防対策の評価に繋げて いく予定である。

連絡先: 蒔田浩平*

酪農学園大学獣医学群獣医疫学ユニット

厂 069-8501 北海道江別市文京台緑町 582 番地

Tel \& Fax : 011-388-4761

E-mail : kmakita@rakuno.ac.jp 


\title{
Assessment of Current Rabies Prevention Act in Japan through Infectious Disease Modelling
}

\author{
Hazumu KADOWAKI ${ }^{1}$, Katie HAMPSON², Kohei MAKITA ${ }^{1}$ and Akio YAMADA ${ }^{3}$ \\ ${ }^{1}$ Veterinary Epidemiology Unit, School of Veterinary Medicine, Rakuno Gakuen University, Ebetsu, Japan \\ ${ }^{2}$ Institute of Biodiversity Animal Health and Comparative Medicine, University of Glasgow, Glasgow, UK \\ ${ }^{3}$ Department of Veterinary Medical Science, Graduate School of Agricultural and Life Sciences, \\ the University of Tokyo, Tokyo, Japan
}

\section{【Objective】}

In Japan, rabies has been eradicated in 1957 after the enforcement of current Rabies Prevention Act, and has not occurred ever since. However, the social situation surrounding dog and human in Japan has been changed, and the risk of transmission of rabies might be different from the past and the review of current Rabies Prevention Act is needed. The objective of this study is to predict rabies transmission dynamics in current Japan using infectious disease modelling reflecting demographical and geographical information.

\section{【Materials and Methods】}

In our study, an individual based model was developed assuming that rabies transmission dynamics was related to the behaviors of dogs and their owners. Parameters used in the simulation were basic reproduction number, serial interval, human population density, vaccination coverage and a probability of occurrence of rabid dog, which was assumed to be dependent on population density and distance from a rabid dog. A dispersal kernel distribution was calculated adjusting previously reported kernel from Tanzanian study. These parameters were estimated using the data of past rabies epidemics in Osaka Prefecture between 1919 and 1933. Hokkaido and Ibaraki Prefectures were selected as study sites for current situation because of their different backgrounds related with rabies transmission risks. The simulation was repeated for 500 times in statistic software, $\mathrm{R}$. To reveal the efficacy of routine vaccination, simulations were performed with reduced vaccination coverage.

\section{[Results and Discussion】}

Basic reproduction number was 2.8, and parameters for population density-dependency and adjustment of the kernel were 2.28 and 2.24, respectively. In Hokkaido Prefecture, the medians of final size of rabid dog cases were 2, 4 and 354, when vaccination coverages were $55 \%, 45 \%$ and $35 \%$, respectively. The medians of duration until epidemic dies out were 53.5 days, 92.5 days and 339.5 days. In Ibaraki Prefecture, final sizes were 2, 3 and 389, at the vaccination coverage 55.6\%, 45.6\% and 35.6\%, respectively. The duration until epidemic dies out were 35 days, 89.5 days and 397.5 days, respectively.

These results suggested that mandatory routine vaccination could reduce final size and duration until epidemic dies out. The model will be updated reflecting the changed rearing style of dogs in current Japan, and the efficacies of several intervention options will be compared. 


\title{
国内養豚生産農場における母豚の妊娠失敗による 淘汰に関連する気象因子と生産因子
}

\author{
谷 里実*・䋶纐雄三
}

明治大学農学部

\section{【目 的】}

本研究の目的は, 繁殖雌豚の妊娠失敗の淘汰に関連する 気象因子と生産因子を特定することであった。

\section{【材料および方法】}

評価したリスク因子は, 日平均気温, 日相対湿度, 初交 配日齢, 分婏時生存産子数, 授乳期間, 離乳後初回交配日 数であった。本研究では, 99 農場に導入された繁殖雌豚 の 240,143 の産次記録と，54,858 の生涯記録を使用した。 気象データは, 99 農場が所在する県の県庁所在地にある 21 の気像観測所より得られた。21 日間の日平均気温の平 均值と日相対湿度の平均值を, 生産記録と統合し分析に用 いた。産次あたりの妊娠失敗による淘汰リスク（\%)は, 妊娠失敗により淘汰された雌豚の産次記録数を種付けされ た雌豚の産次記録数で割り, 100 を掛けることにより算出 した。妊娠失敗による年間化淘汰率（\%）は，妊娠失敗に より淘汰された雌豚数を全雌豚の農場生産日数で割り, 365 （日）と 100 を掛けることにより算出した。産次ごと に一般化線形混合効果モデルを妊娠失敗による淘汰リスク に適用した。

\section{【結果と考察】}

妊娠失敗による産次あたりの淘汰リスク（土SE）は 3.6 $\pm 0.04 \%$ であり，年間化淘汰率は $9.9 \pm 0.13 \%$ であった。 日平均気温の平均 (範囲) は $15^{\circ} \mathrm{C}\left(-10.7-32.7^{\circ} \mathrm{C}\right)$ であり, 日相対湿度の平均は 68\%（19-99\%）であった。

妊娠失敗による高い淘汰リスクは，高い日平均気温，遅 い初交配日齢, 少ない分娩時生存産子数, 遅い離乳後初回 交配日数と関連があったが $(\mathrm{P}<0.05)$, 日相対湿度, 授乳 期間とは関連がなかった $(\mathrm{P} \geq 0.15)$ 。例えば，日平均気温 が $20^{\circ} \mathrm{C}$ から $30^{\circ} \mathrm{C}$ に増加すると, $0-5$ 産次の雌豚の妊娠失 敗による淘汰リスクが 0.4-1.8\% 増加した $(\mathrm{P}<0.05)$ 。ま た初交配日齢が 220 日から 300 日に増加すると，0-2 産次 の雌豚の妊娠失敗による淘汰リスクが 0.4-2.1\% 増加した $(\mathrm{P}<0.05)$ 。分婏時生存産子数が 14 頭から 6 頭に減少する と, 1-5 産次の経産豚の妊娠失敗による淘汰リスクが $0.5-$ $1.8 \%$ 増加した $(\mathrm{P}<0.05)$ 。また, 離乳後初回交配日数が 7 日以上であった 1-5 産次の経産豚は, 離乳後初回交配日数 が 0-6 日であった経産豚と比較して, 淘汰リスクが 1.3$4.9 \%$ 高かった $(\mathrm{P}<0.05)$ 。結論として, 妊娠失敗による 淘汰を減らすために, 冷却マネジメントを整えることと, リスクが高い雌豚に対して注意を払うことを生産者に推奖 する。

\footnotetext{
連絡先 : 谷 里実*

明治大学農学部農学科

T214-8571 神奈川県川崎市多摩区東三田 1-1-1

Tel : 044-934-7826 ; Fax : 044-934-7902

E-mail : composition.013@gmail.com
} 


\title{
Climatic Factors and Production Factors Associated with Culling Risks Due to Pregnancy Failure for Female Pigs in Commercial Herds Located in a Humid Subtropical Climate Zone
}

\author{
Satomi TANI and Yuzo KOKETSU \\ School of Agriculture, Meiji University, Kanagawa, Japan
}

\begin{abstract}
The objective of this study was to determine the climatic and production factors associated with the culling risk for female pigs due to pregnancy failure in commercial breeding herds. The factors assessed were as follows : mean daily average temperature (Tavg), daily average relative humidity, gilt age at first-mating, number of pigs born alive (PBA), lactation length and weaning-to-first-mating interval (WMI). The present study used 240,143 parity records and 54,858 lifetime records of females entered into 99 Japanese herds. The climate data were obtained from 21 weather stations close to the studied herds. Mean daily Tavg and daily average relative humidity for 21 days were coordinated with female's reproductive data. By-parity culling risk due to pregnancy failure (\%) was defined as the number of females culled due to pregnancy failure divided by the number of parity records of mated female pigs $\mathrm{x} 100$. Also, annualized culling rate due to pregnancy failure (\%) was defined as the number of mated female pigs culled due to pregnancy failure divided by the sum of the reproductive herd life days $\times 365$ days $\times 100$. A generalized linear mixed effects model was applied to culling risk. By-parity culling risk $( \pm \mathrm{SE}$ ) due to pregnancy failure was $3.6 \pm 0.04 \%$, and annualized culling rate due to pregnancy failure was $9.9 \pm 0.13 \%$. Mean (ranges) of daily average temperature and average relative humidity were $15^{\circ} \mathrm{C}(-10.7$ to $32.7^{\circ} \mathrm{C}$ ) and $68.5 \%(19-99 \%)$, respectively. An increase in culling risk due to pregnancy failure was associated with higher Tavg, higher aged gilt at first-mating, lower PBA of sows and prolonged WMI $(\mathrm{P}<0.05)$, but not with humidity and lactation length $(\mathrm{P} \geq$ 0.15). For instance, as Tavg increased from 20 to $30^{\circ} \mathrm{C}$, the culling risks of parity $0-5$ females increased by $0.4-1.8 \%(P<0.05)$. Also, the culling risk of parity $0-2$ female pigs increased by $0.4-2.1 \%$ as gilt age at first-mating increased from 220 to 300 days $(\mathrm{P}<0.05)$. As PBA decreased from 14 to 6 pigs, the culling risk of parity $1-5$ sows increased by $0.5-1.8 \%$ ( $\mathrm{P}<0.05)$. Also, in parity $1-5$ sows, the culling risks of sows with WMI 7 days or later were $1.3-4.9 \%$ higher than those of sows with WMI $0-6$ days $(\mathrm{P}<0.05)$. In conclusion, we recommend that producers apply advanced cooling management and equipment for females, and keep an eye on female pigs at risk for reducing female pigs culled due to pregnancy failure.
\end{abstract}




\title{
2010～2012 年の母豚の繁殖成績の推移と 繁殖成績向上に関わる要因分析
}

\author{
石関紗代子 ${ }^{1} \cdot$ 山崎尚則 ${ }^{2} \cdot$ 山根逸郎 ${ }^{2 *}$ \\ ${ }^{1}$ 有限会社サミットベテリナリーサービス \\ 2 農研機構 動物衛生研究所
}

\section{【目 的】}

国際競争力が求められるわが国の養豚産業の中で, 農場 の生産性の向上は急迫した課題である。特に母豚の繁殖成 績の向上は, 離乳頭数の増加に直接貢献し, 群全体の生産 性を上げるために不可欠な要素となっている。豚群の生産 性を反映する疫学指標のうち, 年間種付け雌豚当たり離乳 子豚数 (年間離乳子豚数/母豚) は繁殖成績を代表する指 標とされている。年間離乳子豚数/腹の改善には, 生存産 子数/腹の増加と哺乳中死亡率の低減等が重要であるが, わが国の養豚場におけるこれらの繁殖成績の近年の現状と 指標間の相互関係は不明な点が多い。本研究においては, 2010２012 年に PigINFOに記録された生産成績を用いて, わが国の養豚場の繁殖成績の時系列的な推移を調べた。

\section{【材料および方法】}

養豚場の生産性評価システム（PigINFO）に参加してい る一貫経営の農場（2012 年 113 戸）のうち, 2010 2012 年のすべての年間データが揃っている 68 農場を解析対象 とした。対象農場から得られた生産デー夕を用いて，2012 年の年間離乳子豚数/母豚が上位 $25 \%$ 以上である農場（上 位農場）と上位 $25 \%$ から下位 $25 \%$ までの農場（中位農場） と下位 $25 \%$ 以下である農場（下位農場）に区分した。各 年の各繁殖指標（年間離乳子豚数/母豚，離乳子豚数/腹, 分娩腹数, 生存産子数/腹, 哺乳中死亡率 (\%)) の区分間 の平均值と, 区分内の 3 年間の平均値の推移について反復 測定分散分析を実施し, 平均值に有意差があった場合には
多重比較で群間の差の検定を行った。それぞれの区分内で, 2012 年の各繁殖成績間の関連について, それぞれの農場 の母豚数を制御変数とした偏相関分析を行った。さらに 68 農場のデータベースを, 2012 年の農場の母豚規模に応 じて 4つのグループ（母豚規模：150 頭以下，150３00 頭, 300 600 頭，600 頭以上）に区分し，それぞれの区分間の 繁殖指標の平均值を比較した。

\section{【結果と考察】}

2012 年の繁殖成績が優良な農場（上位農場）は，年間 離乳子豚数/母豚, 離乳子豚数/腹, 生存産子数/腹が期間内 に増加したが $(P<0.05), 2012$ 年の繁殖成績が中位以下 の農場では変動がなかった。すべての区分の農場で生存産 子数/腹と哺乳中死亡率の有意な正の相関（相関係数：上 位, 中位, 下位農場でそれぞれ $0.67,0.67,0.50)$ が認め られ，高い産子数を達成するも，哺乳期の死亡で多くの子 豚を失っている実態が明らかになった。また，母豚規模に よる比較の結果, 母豚規模 600 頭以上の農場の分娩腹数は 母豚規模 150 頭以下の農場よりも有意に高かったが $(P<$ $0.05)$, それ以外の繁殖指標には母豚規模の違いによる平 均值の差は認められなかった。上位農場の結果から繁殖成 績が優良である農場で繁殖成績を向上させるためには，生 存産子数の増加と哺乳中死亡率を抑えた離乳子豚数/腹の 増加が重要であった。一方, 下位農場の結果から繁殖成績 が劣っている農場で繁殖成績を向上させるには, 分婏腹数 の増加と離乳子豚数/腹の双方の改善が重要と考えられた。

連絡先 : 山根逸郎*

国立研究開発法人

農業・食品産業技術総合研究機構

動物衛生研究所ウイルス・疫学研究領域

干305-0856 茨城県つくば市観音台 3-1-5

Tel \& Fax : 029-838-7829

E-mail : iyamane@affrc.go.jp 


\title{
Parameters Contributing to Improved Reproductive Performance on Farrow-to-Finish Swine Farms in Japan
}

\author{
Sayoko ISHIZEKI ${ }^{1}$, Hisanori YAMAZAKI ${ }^{2}$ and Itsuro YAMANE ${ }^{2}$ \\ ${ }^{1}$ Summit Veterinary Services, Gunma, Japan \\ ${ }^{2}$ National Institute of Animal Health, National Agriculture and Food Research Organization, Ibaraki, Japan
}

\begin{abstract}
Data obtained from 68 farrow-to-finish swine farms were used to evaluate reproductive performance and determine factors that are important to improve performance. Pigs weaned per mated female per year (PWMFY), pigs weaned per litter (PWL), and pigs born alive per litter (PBA) increased between 2010 and 2012 among farms with high reproductive performance in 2012 (HP farms). No change was detected in these parameters on farms with normal and low reproductive performance in 2012 (NP and LP farms, respectively). A significant correlations between PBA and preweaning mortality risk (PRWM) were observed on all farm groups classified by reproductive performance, indicating that high numbers of piglets born in these farms were being lost during the suckling stage. Therefore, increasing PWMFY on HP farms will require increasing PWL by increasing PBA and decreasing PRWM, because litters per mated female per year (LMFY) has limited room for improvement. On the other hand, increasing PWMFY can be accomplished by improving both PWL and LMFY among LP farms.
\end{abstract}




\title{
オーエスキー病ウィルスの有無の 養豚場の生産性に与える影響について
}

\author{
山根逸郎 $^{1 *} \cdot$ 石関紗代子 $^{2} \cdot$ 山崎尚則 ${ }^{1}$ \\ ${ }^{1}$ 農研機構 動物衛生研究所 \\ 2 有限会社サミットベテリナリーサービス
}

\section{【目 的】}

わが国では豚オーエスキー病（AD）に対する清浄化対 策が実施されてきたが，2014 年 3 月時点でオーエスキー 病ウイルス (ADV) の野外株が一部の地域で認められて いる。一方, ADV 保有状況の生産性への影響について評 価した報告は少ない。そこで本研究では, 養豚場の生産性 評価システム（PigINFO）に参加している農場のうち, $\mathrm{ADV}$ 陽性県の農場を抽出し, 農場の ADV 保有状況と生 産性との関係を調べた。

\section{【材料および方法】}

調查期間は, 2011 年 1 月 1 日から 12 月 31 日とした。 対象とする農場群は, 日本養豚開業獣医師協会の獣医師の 顧客農場のうち, 2011 年初頭に ADV 陽性農場を有する県 から得られた一貫経営の農場（ $\mathrm{n}=48 ）$ とした。これらの 農場の肥育豚 $(60,90,120$, および 150 日齢) と繁殖豚 (3 産未満群，3産以上群）からそれぞれ 3 頭ずつ計 18 頭の 採血を, 2011 年に 2 回行った (計 36 頭)。得られた血液 サンプルを用いて, ADV 野外株に対する ELISA 抗体検查 を行った。抗体検查で 1 頭でも陽性豚が摘発された農場を 陽性農場, それ以外の農場を陰性農場とした。解析対象と する生産成績は, 各農場の獣医師を通して PigINFOに提 出された 2011 年のデー夕を用い, 出荷頭数 (/母豚/年), 離乳子豚数 (/母豚/年), 離乳子豚数 (/腹), 分婏腹数 (/年), 生存産子数 $($ 腹 $)$, 分婏率 $(\%)$, 離乳後死亡率 $(\%)$, 哺
乳中死亡率（\%) とした。これら生産成績の平均值を陽性 農場と陰性農場で比較し ( $\mathrm{t}$ 検定), 差が認められた指標（p <0.1）に関しては, 重回帰分析を用いて母豚数を調整し た上で陽性農場と陰性農場で平均值に有意差があるか検定 を行った。

\section{【結果と考察】}

ADV 陽性農場は, 全体の 25\%（12/48）に認められた。 $\mathrm{ADV}$ 陽性農場の離乳後死亡率（6.84\%）は，陰性農場の離 乳後死亡率 $(4.73 \%)$ に比べて有意に高かった $(\mathrm{p}<0.01)$ 。 離乳後死亡率が ADV 陽性農場で有意に高かった理由は, 対象農場の多くが他の呼吸器感染症 (Actinobacillus pleuropneumoniae や Mycoplasma hyopneumoniae) を有しており, $\mathrm{ADV}$ との複合感染の可能性が示唆された。母豚数を説明 変数に加えた重回帰分析の結果, ADV 陽性農場は, 陰性 農場に比べて離乳後死亡率が有意に高く $(\mathrm{p}<0.01)$, 出荷 頭数，分娩腹数，分娩率が有意に低かった $(\mathrm{p}<0.05)$ 。 ADV 陽性農場で分婏腹数や分娩率が低かったことから, $\mathrm{ADV}$ 感染が繁殖成績の低下に影響を与えている可能性が 示唆された。

$\mathrm{ADV}$ による離乳後死亡率の上昇による損失に加えて, ワクチンの費用, 動物の出荷や導入に関わる制限, 検査の 費用など, さらなる損失も推定される。今後, 生産者, 獸 医師，行政部局が協力して，AD の撲滅に取り組む事が重 要である。

連絡先 : 山根逸郎*

国立研究開発法人

農業・食品産業技術総合研究機構

動物衛生研究所 ウイルス・疫学研究領域

于305-0856 茨城県つくば市観音台 3-1-5

Tel \& Fax : 029-838-7829

E-mail : iyamane@affrc.go.jp 


\title{
Aujeszky's Disease and the Effects of Infection on Japanese Swine Herd Productivity : a Cross-sectional Study
}

\author{
Itsuro YAMANE ${ }^{1}$, Sayoko ISHIZEKI ${ }^{2}$ and Hisanori YAMAZAKI ${ }^{1}$ \\ ${ }^{1}$ National Institute of Animal Health, National Agriculture and Food Research Organization, Ibaraki, Japan \\ ${ }^{2}$ Summit Veterinary Services, Gunma, Japan
}

Pseudorabies virus (PRV) is endemic in some regions of Japan. We investigated the effects of PRV infection status on herd productivity. We obtained serum samples from 48 swine herds in Japan. Within each herd, three serum samples were obtained from growing pigs at four different ages, and from sows in low and high parity groups. Sera were tested for antibodies against wild-type PRV using competitive ELISA. Herds were classified into PRV positive and negative status based on serological results. Herds infected with PRV exhibited postweaning mortalities $(6.84 \%)$ that were significantly $(P=0.0018)$ higher than those in unaffected herds (4.73\%). Due to the reduced productivity in PRV positive herds, the current PRV eradication program must be strengthened. 


\title{
犬・猫の保険金支払いデータの疫学研究への利用に関する検討
}

\author{
垣内仁志 ${ }^{1 *} \cdot$ 井上 舞 $^{1} \cdot$ 兵藤未来 $^{1} \cdot$ 長谷川篤彦 $^{2}$ \\ ${ }^{1}$ アニコム損害保険株式会社・社アニコム パフェ株式会社
}

\begin{abstract}
【背 景】
ペット保険の保険金支払いデータを用いた疫学研究利用 は, イギリスやスウェーデンで先行しており, 乳腺腫瘍, アトピー性皮膚炎, 心疾患, 糖尿病などの疾患において品 種別や地域別などの罹患率が調査されている。加えて, ス ウェーデンでは請求理由の傷病名の精度検証も実施されて いる。

国内に抒いては，アニコム損害保険株式会社（以下，ア ニコム損保）が犬猫向けのペット保険を引き受けており, 少額・頻回の保険金請求により年間 230 万件を越える量の 保険金支払いデータが蓄積されている。
\end{abstract}

\section{【目 的】}

我々はこの保険金支払いデー夕を疾患デー夕として捉 え, 小動物獣医療における疾患統計に利用している。具体 的には, 国内の学会発表やアニコム損保発行の「アニコム 家庭どうぶつ白書」において, 診断名別に犬猫の有病率を 算出し分析を試みてきた。一方で, 傷病名の精度検証は課 題として残されていた。

アニコム損保の保険契約者が提携動物病院の空口で補償 を受けた場合, その保険金請求は, 動物病院より送付され る電子媒体あるいは紙媒体のレセプトに基づき行われ, 傷 病名を含む診療情報の申告を受ける。しかしながら, 確定 診断の直後などでは, 診断名ではなく初診時の症状名が継 続して申告される例が散見されており，カルテなどに記載 の診断名を検証することが, 保険金支払いデー夕の疫学研 究利用の上では重要であると考えた。そこで, 本研究では, 動物病院への聞き取りを通して, 診断名と保険金支払い データとの整合性を比較検証した。

\section{【材料および方法】}

アニコム損保のペット保険に契約している犬 395 頭およ び猫 40 頭の保険金支払いデー夕 435 件を対象とした。 2014 年 1 月 6 日から 2015 年 1 月 6 日の間に, 保険契約動 物が受診した動物病院へ電話し, 診断名を含む聴取内容を データベース化した。保険金支払いデータ上の診断名と聴 取内容の整合性については, 盲検的に 2 名でデータベース を確認することにより検証した。

\section{【結果と考察】}

計 435 件の電話聴取を実施し，うち 383 件で有用なデー 夕を得た。保険金支払いデータ上の診断名に関して, 動物 病院から聴取した診断名とレセプトに記載された診断名と が一致する確率は 84.9\%（325/383）であった。また，不 一致データの多くは, 診断名が確定した後も初診時の症状 名を申告する請求であった。なお，スウェーデンに打ける 調查に扔いても同様の結果（診断名の正誤率 : $84 \%$ ）が報 告されている (Egenvall A et al., Prev Vet Med 1998 ; 36 : 5165)。以上より，保険金支払いデータにおける診断名の精 度は高く, 疫学研究への利用は可能であることが示唆され た。

一般的に，母集団を年齢や品種ごとに設定しそれぞれの 有病率を比較することにより,その母集団の特徵が現れる。 今後, 当社の保険金支払いデー夕を基に算出した有病率な どの疾患情報が積極的に活用されることを期待している。 さらに, 疾患統計によって明らかとなった事実が動物病院 と飼育者の相互理解に活用され, 疾患予防につながれば幸 いである。

連絡先 : 垣内仁志*

アニコム損害保険株式会社

テ161-0033 新宿区下落合 1-5-22アリミノビル 4F Tel : 03-5348-3777; Fax : 03-6863-8257

E-mail : m.inoue@ani-com.com（連絡先 : 井上 舞） 


\title{
Epidemiological Analysis on Canine and Feline Clinical Data from Japanese Animal Health Insurance Claims Data
}

\author{
Hitoshi KAKIUCHI ${ }^{1}$, Mai INOUE${ }^{1}$, Miku HYODO ${ }^{1}$ and Atsuhiko HASEGAWA ${ }^{2}$ \\ ${ }^{1}$ Anicom Insurance, Inc. \\ ${ }^{2}$ Anicom Pafe, Inc.
}

The data in animal health insurance claims are potentially useful for epidemiological research in veterinary medicine. The consistency of the diagnosis for each claim is important. However, the quality of Japanese insurance data has not yet been validated. The purpose of this study was to clarify the validation between insurance data and telephone interview for veterinarian. Records of 435 cases were sampled from the health insurance claim data from results over 540,000 dogs and cats a company which insured. In 383 of the 435 records, the diagnoses were compared between claims data and telephone interview. As a result of the consistency test, the diagnoses coincided in 347 of 383 (90.6\%) records. In the other records, the inconsistencies were created by inaccurate data input into the system where the original diagnosis from the initial examination was not updated in the database, even after the diagnosis changed as the treatment progressed. Therefore it is concluded that there is a high rate of consistency in the diagnosis between claims data and clinical records. It is felt that Japanese animal health insurance claims data may be available to veterinary epidemiological research. 


\title{
日本の飼い犬における血液寄生へモプラズマ感染の PCR による検出
}

\author{
渡辺 征 $^{1 *} \cdot$ 久末正晴 ${ }^{2} \cdot$ 瀬川和仁 ${ }^{2} \cdot$ 根尾櫻子 ${ }^{2} \cdot$ 土屋 亮 $^{2}$ \\ ${ }^{1}$ 渡辺獣医科医院. ${ }^{2}$ 麻布大学獣医学部内科学第 2 研究室
}

\begin{abstract}
【目 的】
犬へモプラズマ症は赤血球表面に寄生する無細胞壁の培 養不能のマイコプラズマによる感染症で, Mycoplasma haemocanis (Mhc) と 'Candidatus Mycoplasma haematoparvum’（CMhp）の 2 種が知られている。感染による症 状は無症状であったり曖昧な場合が一般的であるが, 脾摘 犬や免疫抑制犬では貧血が見られることが報告されてい る。このようにへモプラズマ感染の臨床的重要性について は今だ未定である。犬へモプラズマは世界的に, 特に地中 海沿岸諸国, 北米, アフリカで流行が報告されている。日 本の飼い犬におけるへモプラズマの流行に関する報告は少 なく, 佐々木ら（2008 年）による Mhc の報告があるが, CMhp については調べていない。通常の感染検出法は血液 の塗抹を Wright-Giemsa 染色し, X1000 油浸で鏡検すると, 赤血球上に赤紫色の斑点として見える。しかし，染色ゴミ と識別は困難であり主観的にならざるを得ないために信頼 性に欠ける。そこで, 寄生体の遺伝子を客観的に検出する ポリメラーゼ連鎖反応法（PCR）を用いて日本の飼い犬に おけるへモプラズマの感染状況を調べたので報告する。
\end{abstract}

\section{【材料と方法】}

合計 741 頭の犬の由来は麻布大学付属動物病院 $(n=391$; $\mathrm{PCV}, 41 \pm 8 \%)$ と動物検查会社（ $\mathrm{n}=350 ; \mathrm{PCV}, 37.9 \pm 28.3 \%)$ で，2011〜2012 年に収集した。内訳は雄（ $\mathrm{n}=366,49.4 \%)$, 雌 $(\mathrm{n}=237,32 \%)$ および不明（n=138, 18.6\%）であり， 品種は血統種が 344 頭 (46.4\%), 雑種が 142 頭 (19.2\%),
不明が 255 頭 (34.4\%) であった。ゲノム DNA は血液 $200 \mu \mathrm{l}$ から NucleoSpin QuickPure キット (Macherey-Nagel) により抽出した。16S rRNA PCR 用プライマーは Barker ら の配列を用いた。血液の塗抹染色標本の鏡検で Babesia gibsoni（BG）原虫の併発感染を疑う例は, P18 遺伝子の プライマーを用いて PCR を行った。

\section{【結果と考察】}

PCR 検査の結果, 741 頭の飼い犬から Mhc 陽性が 30 頭 (4\%), CMhp 陽性が 22 頭 (2.9\%), 両方陽性が 6 頭（0.8\%) の合計 58 頭（7.8\%）が検出された。Mhc 陽性 30 頭中 10, CMhp 陽性 22 頭中 5, 両方陽性 6 頭中 6 例が PCV $37 \%$ 以 下の貧血を示したが，これが感染によるものかは不明で, 両方感染 6 頭の貧血は感染によるものかどうかは例数が少 なく結論はできない $(\mathrm{P}<0.0735)$ 。一方, BG との共感染 として Mhc + BG が 4 例 (0.5\%), CMhp + BG が 7 例 (0.9\%), $\mathrm{Mhc}+\mathrm{CMhp}+\mathrm{BG}$ のトリプル感染が 1 例 $(0.1 \%)$ 検出さ れた。これらを合わせると感染陽性は合計 70 例 $(9.4 \%)$ となった。これら共感染犬は全て中等度の貧血を示したが, それは BG 感染によるものと考えられる。感染のリスク ファクターとしては, Mhc は 5 10 歳 $(\mathrm{n}=16)$ の雌 $(\mathrm{n}$ 18）が多く, CMhpは 5 10 歳 $(\mathrm{n}=12)$ の雌 $(\mathrm{n}=11)$ が多かった。品種は Mhc, CMhpに共通してマルチーズ, ミニチュア・ダックスフンド, ラブラドル・レトリバーが 多かった。本報告から犬へモプラズマ感染は日本国内の飼 い犬において広く蔓延していることが推察された。

\footnotetext{
連絡先: 渡辺 征* 渡辺獣医科医院 干242-0002 神奈川県大和市つきみ野 7-17-36 Tel \& Fax : 046-275-0240 E-mail : hnbns289@ybb.ne.jp
} 


\title{
Detection of Canine Hemoplasma Infection Using PCR in the Japanese Domestic Dogs
}

\author{
Masashi WATANABE ${ }^{1}$, Masaharu HISASUE ${ }^{2}$, Kazuhito SEGAWA², Sakurako NEO² and Ryou TSUCHIYA ${ }^{2}$ \\ ${ }^{1}$ Watanabe Veterinary Clinic, Laboratory of Veterinary Internal Medicine II, \\ ${ }^{2}$ School of Veterinary Medicine, Azabu University
}

Two canine hemoplasma species (Mycoplasma haemocanis [Mhc] and 'Candidatus Mycoplasma haematoparvum [CMhp]) are hemotrophic mycoplasma that parasitize on the surface of a red blood cell. These parasites has been reported to be associated with anaemia in splenectomised dogs. Generally asymptomatic or ambiguous infection are reported to occur in healthy adult animal, but severe anemias are associated with co-infection with multiple hemoplasma species. The clinical importance of canine hemoplasmas has not been defined. Epidemiological survey in Japanese domestic dog has been reported by a molecular survey of Mhc infection alone in dogs and foxes in Aomori Prefecture, Japan (Sasaki, et al. 2008). Some studies demonstrated that canine hemoplasmas were distributed world wide, especially among Mediterranean countries, North America and Africa. Microscopic detection is difficult due to small cocci and low parasitic rate. Thorefore, we used molecular method of polymerase chain reaction (PCR) for the detection of two canine hemoplasma infections. A total of 741 blood samples was collected from domestic dogs at Azabu University Teaching Hospital ( $n=391$; PCV, $41 \pm 8 \%)$ and Veterinary Laboatory $(n=350 ;$ PCV, 37.9 $\pm 28.3 \%)$ between 2011 and 2012. PCR was carried out for the detection of 16S rRNA gene of parasite using DNA extracted from dog blood by NucleoSpin Blood Quick Pure kit (Macherey-Nagel), primer set designed by Barker et al. (2010) and GoTaq Green master mix (Promega). The cycling conditions comprised initial denaturation at $95^{\circ} \mathrm{C}$ for $10 \mathrm{~min}$ followed by 32 cycles of amplification $\left(1 \mathrm{~min}\right.$ at $94^{\circ} \mathrm{C}, 1 \mathrm{~min}$ at $51.5^{\circ} \mathrm{C}$ for $\mathrm{Mhc}$ and $57.4^{\circ} \mathrm{C}$ for $\mathrm{CMhp}$, and $2 \mathrm{~min}$ at $72^{\circ} \mathrm{C}$ ), and a final extension of $7 \mathrm{~min}$ at $72^{\circ} \mathrm{C}$. We found the infection cases accompanied by protozoan Babesia gibsoni (BG). PCR protocol for detecting BG is initial denaturation at $95^{\circ} \mathrm{C}$ for 2 min followed by 30 cycles (30 seconds at $94^{\circ} \mathrm{C}, 1 \mathrm{~min}$ at $53.8^{\circ} \mathrm{C}$ and $1 \mathrm{~min}$ at $72^{\circ} \mathrm{C}$ ). Sensitivity of PCR assay for detecting $16 \mathrm{~S}$ rRNA gene of canine hemoplasmas was determined to be $1 \mathrm{pg}$ for Mhc and $19.7 \mathrm{pg}$ for CMhp using cloned pCR2.1-TOPO vector (Invitrogen). A total of 58 of the $741 \mathrm{dogs}$ (7.8\%) were positive as 30 (4\%) for Mhc alone, 22 (2.9\%) for CMhp alone, and $6(0.8 \%)$ dually infected. Relationship between PCV values and infection species showed anemia in dual infection alone. While, as the co-infection with BG, $4(0.5 \%) \mathrm{Mhc}+\mathrm{BG}, 7(0.9 \%)$ $\mathrm{CMhp}+\mathrm{BG}$ and $1(0.1 \%) \mathrm{Mhc}+\mathrm{CMhp}+\mathrm{BG}$ were detected. PCV values in co-infected dogs with BG decreased, indicating that these are due to BG infection. Risk factors for hemoplasmas infection was 5-10 years old or more aged dog and Maltese, Miniature Dachshund and Labrador Retriever as the breed. The hemoplasma-infected dogs in our study did not always exhibit clinical signs, e.g., anemia clearly attributable to hemoplasma infections. In brief, we detected 70 (9.4\%) hemoplasma-positive dogs including 12 coinfected dogs with BG. 


\title{
日本の猫の下部尿路疾患と飼育状況の関連調査
}

\author{
檀 華子*·河本光祐 $\cdot$ 井上 舞 \\ アニコム損害保険株式会社
}

\section{【背 景】}

猫の下部尿路疾患 (FLUTD) は, 頻尿, 不適切な場所 での排尿, 疼痛性排尿困難, 血尿を認める疾患の総称であ る。具体的には, 尿路結石, 尿路感染, 外傷, 特発性膀胱 炎 (FIC : Feline Idiopathic Cystitis) などがあるが,このうち, 最も多いのはFIC であり, FLUTD の約 $60 \%$ を占めている とされる。特に FIC では, 明確な原因は不明だが, 危険 因子に関しては品種や年齢等の報告がある。

本研究では, ペット保険加入猫へのアンケート調查をも とに, 日本の猫における品種や性別, 年齢等に加えて飼育 環境や食事管理, 家族構成等と FLUTD の関連を調查し, リスク因子の特定を試みた。

\section{【対象および方法】}

2015 年 1 月時点でアニコム損害保険株式会社において 契約のある猫の飼主に対しアンケートを実施した。回答が あった猫を FLUTD の既往歴がある群と, 既往歴がない群 に分け, それぞれ品種, 性別, 年齢, 体型, 生活環境 (多 頭飼育, 家族構成, 家の広さ, 温度調整, 騒音, トイレの
数等）について比較検討した。

\section{【結果と考察】}

有効回答数は 942 件であり, FLUTD の既往歴がある猫 は $24.3 \%$ ，既往歴のない猫は $75.6 \%$ であった。単頭飼育と 多頭飼育の比較では，多頭飼育猫の方が有意に既往率が高 かった。 $(\mathrm{P}=0.01, \mathrm{OR}=1.48)$ ささらに, 騒音がある環境 とない環境にそれぞれ飼育されている猫で比較すると, 騒 音がある環境で生活している猫の方が FLUTD 既往率は有 意に高かった。 $(\mathrm{P}=0.04, \mathrm{OR}=1.45)$ 。

その他, 性別, 家族の人数, 家庭内の子供の有無, 家の 広さや来客頻度, 温度管理や遊び場の有無, トイレの数, トイレの清掃頻度を同様に検証したが, FLUTDの既往率 について有意な差は認められなかった。

FLUTD のリスク因子としては様々なものが考えられて いるが, 特に同居猫との間に生じるストレスや, 騒音スト レスが強く影響を与えていることが示唆された。これらの 除去, あるいは軽減によって, FLUTDの発症を予防でき る可能性が考えられる。

\footnotetext{
連絡先 : 檀 華子*

アニコム損害保険株式会社

テ161-0033 新宿区下落合 1-5-22 アリミノビル 4F

Tel : 03-5348-3777 ; Fax : 03-6863-8257

E-mail : hanako.dan@ani-com.com
} 


\title{
Questionnaire Analysis on the Relation between Feline Lower Urinary Tract Disease and Feeding Environment in Japanese Cats
}

\author{
Hanako DAN, Kosuke KAWAMOTO and Mai INOUE
}

Anicom insurance, Inc.

\section{【Introduction】}

Feline lower urinary tract disease (FLUTD) is the generic term of urinary tract stone, urinary tract infections, idiopathic cystitis (FIC), and trauma. FIC occupies around $60 \%$ of FLUTD, but the cause and effective treatment are not yet clearly understood. In some studies, it was indicated that stress from feeding environment may cause FIC. This investigation was based on a questionnaire survey conducted to clarify inherent risks of FLUTD in Japanese insured cats.

\section{[Materials and Methods】}

Information was obtained through surveys conducted with cat owners contracted with Anicom pet insurance up until January 2015. After collection of survey questionnaire, cats were classified into FLUTD and non FLUTD groups, and also were both compared by 23 survey items, which included individual information and feeding environments.

\section{【Results and Discussion】}

Information from 942 cats was collected through the questionnaire. 229 cats were classified into FLUTD group and 713 cats were classified into non FLUTD group. Amongst the 23 survey items, group feeding and noise, which owner can recognize in house, had significant affect on FLUTD. There were no significant differences between FLUTD group and non FLUTD group in the other 21 survey items. Therefore it is thought that reducing the stress from group feeding and household noise may prevent cats from falling FLUTD. 


\title{
防疫チームにおけるコミュニケーション上の課題と 演習「やぐら鶴」の効果
}

\author{
柴田正志 ${ }^{1 *} \cdot$ 堀北哲也 ${ }^{2}$ \\ ${ }^{1}$ 静岡県中部家畜保健衛生所 ${ }^{2}$ ちば NOSAI 連中央家畜診療所
}

\begin{abstract}
【目 的】
鳥インフルエンザや口蹄疫発生時に行う防疫作業は, 面 識のない者同士での作業となることが多いため, 防疫チー ム内でコミュニケーションやチームワークが機能しないと いう課題が考えられる。そこで, 防疫作業の現場で具体的 にどのようなコミュニケーション上の問題があったかを明 らかにするために, 防疫作業従事者を対象に聞き取り調査 を実施した。さらに, 聞き取り内容をもとに, チームワー クをトレーニングするための演習「やぐら鶴」を考案しそ の効果を検証した。
\end{abstract}

\section{【材料および方法】}

1. 口蹄疫の防疫作業に派遣された人への聞き取り調査 2010 年に宮崎県で口蹄疫が発生した際, 県外から防疫 作業に派遣された 10 名を対象に聞き取り調査を実施した。 調査期間は 2012 年 7 月から 2013 年 7 月まで, 調查対象者 は, 畜産団体職員 4 名, NOSAI 獣医師 2 名, 家畜保健衛 生所職員 2 名, 開業獣医師 1 名および大学教員 1 名であっ た。聞き取り時間は一人当たり約 2 時間, 聞き取り方法は, 「コミュニケーション上の課題は何かありましたか」など 大まかな質問項目のみを設定する半構造化インタビューと した。聞き取り内容をテキスト化してその内容を KJ 法に より分析した。

2. チームワークトレーニング演習「やぐら鶴」の考案と その効果

やぐら鶴は班対抗のカードゲームで, 1 組 41 枚のカー ドにゲームに勝つための情報が分散されて記述されてい る。各班に与えられた 1 組のカード全てを班員に配り, 班 員は自分の手にした数枚のカードに書かれた情報を口頭で 伝えることはできるが見せてはいけないルールになってい る。班内でカードの情報を統合し, 役割分担して作業にあ

連絡先 : 柴田正志*

静岡県中部家畜保健衛生所

干427-0007 静岡県島田市野田 1120-1

Tel : 0547-37-1158

E-mail : masashi1_shibata@pref.shizuoka.lg.jp
たるなど，チームの連携を図りコミュニケーションをとら ないとゲームに勝てない仕組みになっている。

演習「やぐら鶴」は, (1)宮崎県の口蹄疫防疫対策事例紹 介（約 20 分）(2)チームワークについてのミニ講義（約 20 分), (3)ゲームやぐら鶴の実施 (約 1 時間), (4)ゲーム内で 起きたコミュニケーション等の課題についてのふりかえり (約 40 分) の順で行い, 全体で約 2〜3 時間を要した。こ の演習を 2014 年 9 月から 2015 年 1 月の間に 9 か所, のべ 229 人を対象に実施した。

ふりかえりの時間に参加者から述べられた発言をマイン ドマップ法により分析することで演習の効果をみた。また, 参加者の対人関係の能力（ソーシャルスキル）の変化を計 測するため, Kikuchi's Scale of Social Skills : 18items（以下, KiSS-18）を演習の前後に実施し, Wilcoxon 順位和検定に より評価した。

\section{【結果および考察】}

聞き取り調査の結果, 防疫作業の現場には, 慣れないメ ンバーとの作業の不自由さ, 情報伝達の不備, リーダーへ の不満, 指示の出し方の難しさ等, チームワーク上の問題 が多くあった。

やぐら鶴を実施した結果，「突然のリーダー指名による 重圧を感じた」「目先に夢中になり周囲が見えなくなった」 「思い込みにより情報伝達ができなかった」など口蹄疫防 疫参加者と同様のチームワーク低下の状況が再現できた。 また参加者の KiSS-18 平均スコアは, やぐら鶴実施前 $55.96 \pm 11.34$ から実施後 $60.00 \pm 12.65$ に向上し $(\mathrm{p}<0.01)$, やぐら鶴演習がチームワークやコミュニケーション能力を 向上させることが期待できた。

防疫チームを機能させるには, 日頃から発生に備えたマ ニュアルの整備や防疫演習などいわゆるコンテントを重視 した演習の実施が重要である。しかし同時に, コミュニケー ションやチームワークなど人と人との関係性，いわゆるプ ロセスも重要である。そこで「やぐら鶴」のようなプロセ ス体験型の演習が必要であり, これを防疫演習に組み込む ことで家畜伝染病発生時の防疫対応に備えた有効なトレー ニングができると考える。 


\title{
The Cases of Miscommunication in Teams for Foot and Mouth Disease Control, and the Effect of the Workshop "Yagura-tsuru (The Crane on the Tower)"
}

\author{
Masashi SHIBATA ${ }^{1}$ and Tetsuya HORIKITA ${ }^{2}$ \\ ${ }^{1}$ Shizuoka Prefectural Chubu Livestock Disease Diagnostic Center \\ ${ }^{2}$ Chiba Prefectural Federation of Agricultural Mutual Aid Association
}

\begin{abstract}
There were outbreaks of foot and mouth disease (FMD) in Miyazaki in 2010. Many teams were organized for preventive measures for FMD, and the members of teams were required good communications. But, it was supposed that there would be miscommunications in the teams. Then, we had interviews with ten persons of the task groups for FMD and define of cases about miscommunications. And, we device the game named "Yagura-tsuru (The crane on the tower)" for training of team communication, and verify the effect of workshops using it. Players of this game in the workshop were requires to integrate of information, to carry out their responsibility, and to be cool and steady. The workshops were carried out at nine times from September 2011 to February 2015 to 229 participants. The change of communication skill of participants were estimated by KiSS-18.

In the results, there were many cases of miscommunications on the FMD teams. And, the game of "Yagura-tsuru" could reappear the same situation as the team of FMD control at Miyazaki. The pre-point and post-point of KiSS-18 were 55.96 $\pm 11.34,60.00 \pm$ $12.65(\mathrm{p}<0.01)$, respectively. The workshop "Yagura-tsuru" was prospected that training tool for communication of teams for preventive measures of infectious diseases.
\end{abstract}




\title{
家畜感染症対策における農家の知識と隠匿行動 一マダガスカルとスリランカの事例一
}

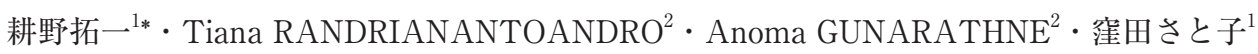 \\ ${ }^{1}$ 帯広畜産大学畜産衛生学研究部門 $\cdot{ }^{2}$ 帯広畜産大学畜産衛生学専攻
}

\begin{abstract}
【目 的】
途上国の音産生産に抢いてアフリカ豚コレラ（ASF）と 口蹄疫 (FMD) の発生がもたらす経済的損失は大きい。 途上国の農家は家畜感染症の知識にそしく, 家畜が FMD などに感染しても, 家畜の市場価值の損失を恐れた農家が, 家畜を密かに市場に販売してしまうという話が聞かれる。 こうした隠匿行動が，途上国に㧍いて家畜感染症が急速に 拡大する要因の一つといわれているが, これまで隠喏行動 を明らかにした研究はない。この研究では, 途上国の適切 な家畜感染症対策に資することを目的に, 途上国農民の感 染症に関わる知識と隠匿行動の関倸について明らかにす る。
\end{abstract}

\section{【分析方法】}

ASF と FMD の発生被害の大きい, マダガスカルの Antananarivo Avaradrano 地区とスリランカの Anuradapura 地区をそれぞれ調査対象地域とした。へロインの利用や人 種偏見の有無について直接訪ねても信頼の扔ける回答を得 られる可能性は低い。Item Count Technique（ICT）は回答
者にとって非常にセンシティブな項目を含む質問でも，間 接的に信頼の扔ける回答を導き出す方法である。我々の調 查では，マダガスカルとスリランカにおいて FMD などに 感染した家畜を，密かに販売する暚匿行動を明らかにする ために ICT を援用した。2013 年 12 月と 2014 年 3 月にマ ダガスカルとスリランカでそれぞれ調査票を用いた実態調 査を実施した。

\section{【分析結果と考察】}

マダガスカルでは，ASF は人間にも感染すると誤った 知識を持つ農家の $83 \%$ が，直接質問では感染豚の販売を 認めなかったが，ICTによる間接質問では，ASF 感染豚を 密かに販売していることが示唆された。一方, スリランカ では，FMD に関する知識レベルの高い $11 \%$ の農家は, FMD 感染牛を密かに販売していることが示唆された。途 上国では, こうした感染家畜の隠匿販売の存在も前提とし た家畜感染症対策が必要であろう。感染家畜を発見しても 殺処分に関わる十分な補償金が得られないことも農家の隠 匿行動の要因と考えられる。農家に感染家畜の報告のイン センティブを与える補償金の仕組みも必要であろう。

連絡先 : 耕野拓一*

帯広畜産大学畜産衛生学研究部門

$\overline{\mathrm{T}} 080-8555$ 北海道帯広市稲田町西 2 線

Tel : 0155-49-5452

E-mail : kono@obihiro.ac.jp 


\title{
Knowledge and Sensitive Behaviour toward Infectious Animal Diseases - Cases of Madagascar and Sri Lanka-
}

\author{
Hiroichi KONO로 Tiana RANDRIANANTOANDRO², Anoma GUNARATHNE ${ }^{2}$ and Satoko KUBOTA ${ }^{1}$ \\ ${ }^{1}$ Department of Animal and Food Hygiene, Obihiro University of Agriculture and Veterinary Medicine, \\ ${ }^{2}$ Graduate School of Obihiro University of Agriculture and Veterinary Medicine
}

\section{【Objective】}

African Swine Fever (ASF) and Foot and Mouth Disease (FMD) pose serious economic threats to livestock production in developing countries. It is often said that farmers have poor knowledge to identify infected animals and they sell infected animals. These are sensitive behaviours that farmers want to keep these things secret. Also, it is one of the critical factors leads to spread infectious disease quickly. Therefore, the objective of this study is to clarify the relationship between farmers' knowledge and sensitive behaviour to control infectious animal diseases.

\section{【Materials and Methods】}

Antananarivo Avaradrano District, Madagascar and Anuradhapura District, Sri Lanka were purposively selected as target areas. Item count technique (ICT) is a method used to elicit respondents' truthful answers to sensitive behaviours such as heroin use and racial prejudice. In our study ICT was used to estimate the sensitive behaviours for an example selling infected animals secretly. A total of 201 farmers in Madagascar and Sri Lanka were interviewed face-to-face in December 2013 and May 2014, respectively.

\section{【Results and Discussion】}

In Madagascar, $83 \%$ of farmers who incorrectly believe that ASF can affect human sell the ASF infected animals but they did not admit it directly. On the other hand, in Sri Lanka, 11\% of farmers who have high level of knowledge sell the FMD infected animals and they want to keep secret. Therefore, strict monitoring should be carried out on farmers who sell infected animals. Furthermore, government should provide compensation as an incentive for prompt reporting of suspicion of diseases to limit the extent. 


\title{
NEAT : Networking to Enhance the Use of Economics in Animal Health Education, Policy Making and Research in Europe and Beyond
}

\author{
蒔田浩平 ${ }^{1 *} \cdot$ Jarkko K. NIEMI ${ }^{2} \cdot$ Agnès WARET-SZKUTA $^{3} \cdot$ Jörn GETHMANN $^{4} \cdot$ Maurizio ARAGRANDE $^{5}$. \\ Henk HOGEVEEN ${ }^{6} \cdot$ Barbara HÄSLER $^{7} \cdot$ Houda BENNANI ${ }^{7} \cdot$ Jonathan RUSHTON $^{7}$ \\ ${ }^{1}$ 酪農学園大学・ ${ }^{2}$ Natural Resources Institute Finland (Luke), ${ }^{3}$ Ecole Nationale Vétérinaire de Toulouse, France • \\ ${ }^{4}$ Friedrich-Löffler-Institut, Germany $\cdot{ }^{5}$ University of Bologna, Italy $\cdot{ }^{6}$ Wageningen UR, The Netherlands • \\ ${ }^{7}$ Royal Veterinary College, United Kingdom
}

\section{【目 的】}

近年世界各地で起きている経済危機を受け, 家畜衛生予 算配分の再評価の必要性が指摘されている。再興新興家畜・ 人獣共通感染症の発生頻度は上昇しており, 疾病発生予防 ならびに制御における意思決定方法を再考する必要性が高 まっている。本プロジェクトは家畜衛生専門家が経済学を より多く利用出来るよう, 経済学教育人材の幅を広げ, ま たその教材を作成することを目的とする。

\section{【材料と方法】}

NEAT コンソーシアムは 63 のパートナー機関（うち EU は 53 機関）で構成され，プロジェクトは 2013 年からの 3 年間で実施されている。各パートナー機関はそれぞれの国 内で協力研究者を募り調查と作成物の普及を実施してい る。具体的内容としては, 協力研究者 (日本は 7 大学 7 名 (うち一大学は農業系学部)）対象のオンライン質問票調查 による家畜衛生経済学の研修・教育で何が不足しているか 特定し, 家畜衛生経済学に関する文献調査を実施した。

この結果を反映し経済学者が作成した教材を，2014年 10 月に獣医学生ボランティアの協力の下評価した。

\section{【結果と考察】}

日本では，NEAT パートナー 1 機関を含む 13 大学と 1
研究機関が協力機関となった。

質問票調査では，ヨーロッパの獣医学教育カリキュラム において 29 獣医学部のうち $31 \%$ のみで「経済学」という 用語が使用されていることが明らかとなった。また獣医学 部のある大学を持つ EU26 か国のうち 5 か国 $(19.2 \%)$ の みで，いずれかの教育過程で家畜衛生経済学コースが開講 されていた。家畜衛生経済学の教育内容には一致性がなく, 研修に関する情報は少ない状況にあった。特に必要とされ ている内容としては，介入に扔ける意思決定と疾病影響評 価が挙げられた。

日本では, 一農学系学部で学部・大学院の両方で家畜衛 生経済学が開講されていた。獣医科大学 6 校では一大学で 獸医疫学講義の中で家畜衛生経済学が教えられていた。一 方 7 機関のうち $57.1 \%$ (4 機関) が国または国際レベルの 研究で家畜衛生経済学を使用していた。

文献調查では, 高病原性疾病, 牛, 先進国に関する研究 が多く見られた。アプローチとしてはシミュレーション $(20 \%)$, レビューと考察 $(16 \%)$, 調查 $(13 \%)$ が一般的で, 畜産関係者の行動の理解に関する新分野での内容は少な かった。

本年は，2014 年の評価以後改良した学部，大学院，卒 後教育カリキュラム案・コース内容・教材の普及が計画さ れている。

連絡先 : 蒔田浩平*

酪農学園大学獣医学群獣医疫学ユニット

T069-8501 北海道江別市文京台緑町 582 番地

Tel \& Fax : 011-388-4761

E-mail : kmakita@rakuno.ac.jp 


\title{
NEAT : Networking to Enhance the Use of Economics in Animal Health Education, Policy Making and Research in Europe and Beyond
}

\author{
Kohei MAKITA ${ }^{1}$, Jarkko K. NIEMI ${ }^{2}$, Agnès WARET-SZKUTA ${ }^{3}$, Jörn GETHMANN ${ }^{4}$, Maurizio ARAGRANDE ${ }^{5}$, \\ Henk HOGEVEEN ${ }^{6}$, Barbara HÄSLER ${ }^{7}$, Houda BENNANI ${ }^{7}$ and Jonathan RUSHTON ${ }^{7}$ \\ ${ }^{1}$ Rakuno Gakuen University, Japan, ${ }^{2}$ Natural Resources Institute Finland (Luke), \\ ${ }^{3}$ Ecole Nationale Vétérinaire de Toulouse, France, ${ }^{4}$ Friedrich-Löffler-Institut, Germany, ${ }^{5}$ University of Bologna, Italy, \\ ${ }^{6}$ Wageningen UR, The Netherlands, ${ }^{7}$ Royal Veterinary College, United Kingdom
}

\section{【Objective】}

Recent world economic crises have highlighted a need to reassess public resource allocation for animal health services. Frequencies of the emergence and re-emergence of animal and zoonotic disease epidemics are increasing, and there is a great need for improving decision making regarding disease prevention and control. The present project aims to enable a wider cadre of people to teach economics and to create educational materials in order to promote the best use of economics by animal health professionals.

\section{[Materials and Methods】}

The NEAT consortium comprising 63 partners (53 from EU and 10 from the other parts of the world) started in 2013 and is running for three years. These partners were encouraged to involve local collaborators for surveys and dissemination of results. Webbased questionnaires were distributed to these collaborators and beyond, including seven Japanese scientists from universities (one from agriculture faculty), to identify the gaps in training and education of economics in animal health (EAH) in the different regions where partners are located. A literature review on economics in EAH was also conducted.

Building on this assessment, training materials were developed by economists, and evaluated by volunteer veterinary students and animal health professionals in October 2014.

\section{【Results and Discussion】}

In Japan, 13 universities including a NEAT partner institute, and a national research institute agreed to collaborate with this project.

According to the questionnaire survey, only $31 \%$ of 29 veterinary faculties within Europe included the term 'economics' in their curriculum. Five (19.2\%) of 26 European countries had veterinary faculties that offer courses tailored towards EAH with varying degrees of intensity. Education in EAH is inconsistently offered and information on training opportunities was scarce. Education needs were related especially to intervention decision and disease impact assessment.

In Japan, an agriculture faculty offered animal health economics at both undergraduate and post-graduate level. Of six veterinary universities, one university was teaching animal health economics as a part of veterinary epidemiology class. For the purpose of research, 57.1\% (4/7) used animal health economics for the problem at the national or international level.

A review found literature to focus on highly contagious animal diseases, bovine, and industrialized countries. Simulation (20\%), review and discussion (16\%), and survey (13\%) were the common approaches, and studies to understand stakeholders' behavior in novel ways were limited.

This year, the project will disseminate curricula, course contents and teaching materials for undergraduate, postgraduate and established professionals, which were evaluated in 2014 and are being improved. 